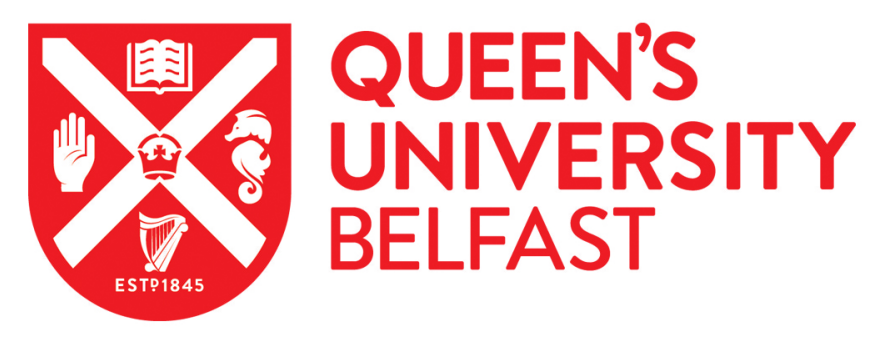

\title{
Triassic: seasonal rivers, dusty deserts and saline lakes
}

Ruffell, A., \& Hounslow, M. (2006). Triassic: seasonal rivers, dusty deserts and saline lakes. In P. F. Rawson, \& P. Brenchley (Eds.), The Geology of England \& Wales. (pp. 295-325). Geological Society of London.

\section{Published in:}

The Geology of England \& Wales.

\section{Queen's University Belfast - Research Portal:}

Link to publication record in Queen's University Belfast Research Portal

\section{General rights}

Copyright for the publications made accessible via the Queen's University Belfast Research Portal is retained by the author(s) and / or other copyright owners and it is a condition of accessing these publications that users recognise and abide by the legal requirements associated with these rights.

Take down policy

The Research Portal is Queen's institutional repository that provides access to Queen's research output. Every effort has been made to ensure that content in the Research Portal does not infringe any person's rights, or applicable UK laws. If you discover content in the Research Portal that you believe breaches copyright or violates any law, please contact openaccess@qub.ac.uk. 


\title{
13 \\ Triassic: seasonal rivers, dusty deserts and saline lakes
}

\author{
M. W. HOUNSLOW \& A. H. RUFFELL
}

The collision of Siberia and the Kazakstan microplate with the eastern side of the Fennoscandia continent in the Permian amalgamated the last major continental fragments to produce the supercontinent Pangaea, which persisted into the Jurassic (Fig. 13.1). During the last phases of this collision, during the latest Permian-Early Triassic, extrusion of massive amounts of flood basalts occurred in Siberia, to the east of the Urals (Otto $\&$ Bailey 1995). Some have proposed this event as one of the key processes controlling the largest extinction in Earth's history at the Permian-Triassic boundary (Wignall 2001a; Benton \& Twitchett 2003).

During the Triassic, England and Wales lay beyond the western termination of the Tethys Ocean, which was divided into a northern part, the Palaeotethys, and a southern part, the Neotethys (Fig. 13.1). Between these oceans occurred the Cimmerian terrains; several now widely separated continental fragments which had rifted from the northern fringe of Gondwana in the Permian (Stampfli \& Borel 2002). The Triassic witnessed the northward drift of these Cimmerian terrains, and the northward subduction of the Palaeotethys, which was mostly completed by the Late Triassic. However, in the western Tethys, some Triassic ocean basin fragments (e.g. Pindos, Meliata) persisted into the Jurassic (Fig. 13.1) (Stampfli $\&$ Borel 2002). The southern margin of the Neotethys Ocean stretched southeastwards through North Africa, Arabia, northern India and NW Australia and shows clastic and carbonate Triassic successions typical of a passive margin (Weidlich \& Bernecker 2003), contrasting strongly with the destructive northern margin of Palaeotethys.

Extensive rift basins formed in Europe during the Triassic, stretching from the Boreal Ocean in the north, through the Greenland-Norwegian gateway into many of the bordering regions around Britain and Ireland, and extending south and SE into France, Iberia and central Europe (Fig. 13.2). This rifting extension was a continuation of Permian rifting and segmented both Caledonide and Variscan basement.

In the same way that the start of the Triassic was heralded by the flood basalts of west Siberia, the end of the Triassic and start of the Jurassic was marked by the extrusion of extensive flood basalts of the central Atlantic magmatic province, which extended along the boundary of the Africa-Americas continental join, from Iberia in the north to Brazil in the south (Marzoli et al. 1999). This extensive flood basalt province, of which only fragments are now seen, has been suggested as one of the decisive elements responsible for the floral and faunal turnover at the end of the Triassic (Wignall 2001a; Cohen \& Coe 2002; Hesselbo et al. 2002; Tanner et al. 2004).

\section{European palaeoenvironmental signatures}

The Permian witnessed the fragmentation of the core of the Variscan Mountains into a number of separate areas, such as the Armorican, Bohemian and Iberian massifs (Fig. 13.2). These supplied sediment northwards into adjacent basins during much of Early and Mid Triassic time. It was only marginal to the Fennoscandia uplands, and during parts of the Carnian (Late Triassic) in Central Europe, that sediment sources switched to the north or NE (Ziegler 1990).

The south polar glaciations, which influenced the Permian, were not a factor in the Triassic, which has no sedimentary evidence of polar ice caps. The Pangaea supercontinent during the Triassic severely perturbed the latitudinal changes in palaeoclimate (Parrish 1993). The interior northern regions of the supercontinent would have experienced low-pressure conditions in the summer, drawing humid air from the Tethys Ocean. Much of this moisture may have precipitated on the remnant Variscan mountains in southern-central Europe and Iberia, leading to northwards seasonal transport of sediment by major river systems. In the winter, the northern interiors would have been sources of dry, externally directed winds. This strongly seasonal monsoonal climate was at its peak during the Triassic and was enhanced by the equatorial position of Tethys, flanked to the north and south by large continental masses (Parrish 1993). Cross-stratification measurements on dune systems in the upper parts of the Sherwood Sandstone Group (Middle Triassic) mostly demonstrate that they were deposited by winds blowing from the Triassic ENE to NNE (Thompson 1970b; Meadows \& Beach 1993; Jones \& Ambrose 1994; Mountney \& Thompson 2002). These may have been the monsoonal dry winter winds emanating from the interior of northern Pangaea. This monsoonal climate would give a strong seasonality, possibly even at the equator (Parrish 1993). Consequently, even though England and Wales drifted northwards during the Triassic from a palaeolatitude of about $16^{\circ} \mathrm{N}-34^{\circ} \mathrm{N}$, this drift may not have radically altered the climate, which was dominated by strong monsoonal circulation. Interior parts of Pangaea may have experienced arid and semi-arid conditions, stretching from near the equator to around $50^{\circ} \mathrm{N}$, and perhaps extending over $80 \%$ of Pangaea in the Early Triassic (Chumakov \& Zharkov 2004).

During the Triassic much of southern Europe (south of the Alps and Caucasus Mountains) comprised a series of faultbounded blocks at the SW termination of the Tethys Ocean (Figs $13.1 \&$ 13.2). The Mid and Late Triassic saw these blocks fragment, and subside, producing fringing and ramp carbonate reefs with intervening deep marine basins.

Within a zone across central Europe (Poland-GermanyDenmark-France-England-Wales-Spain), Triassic basinal 


\section{Permian-Triassic boundary}

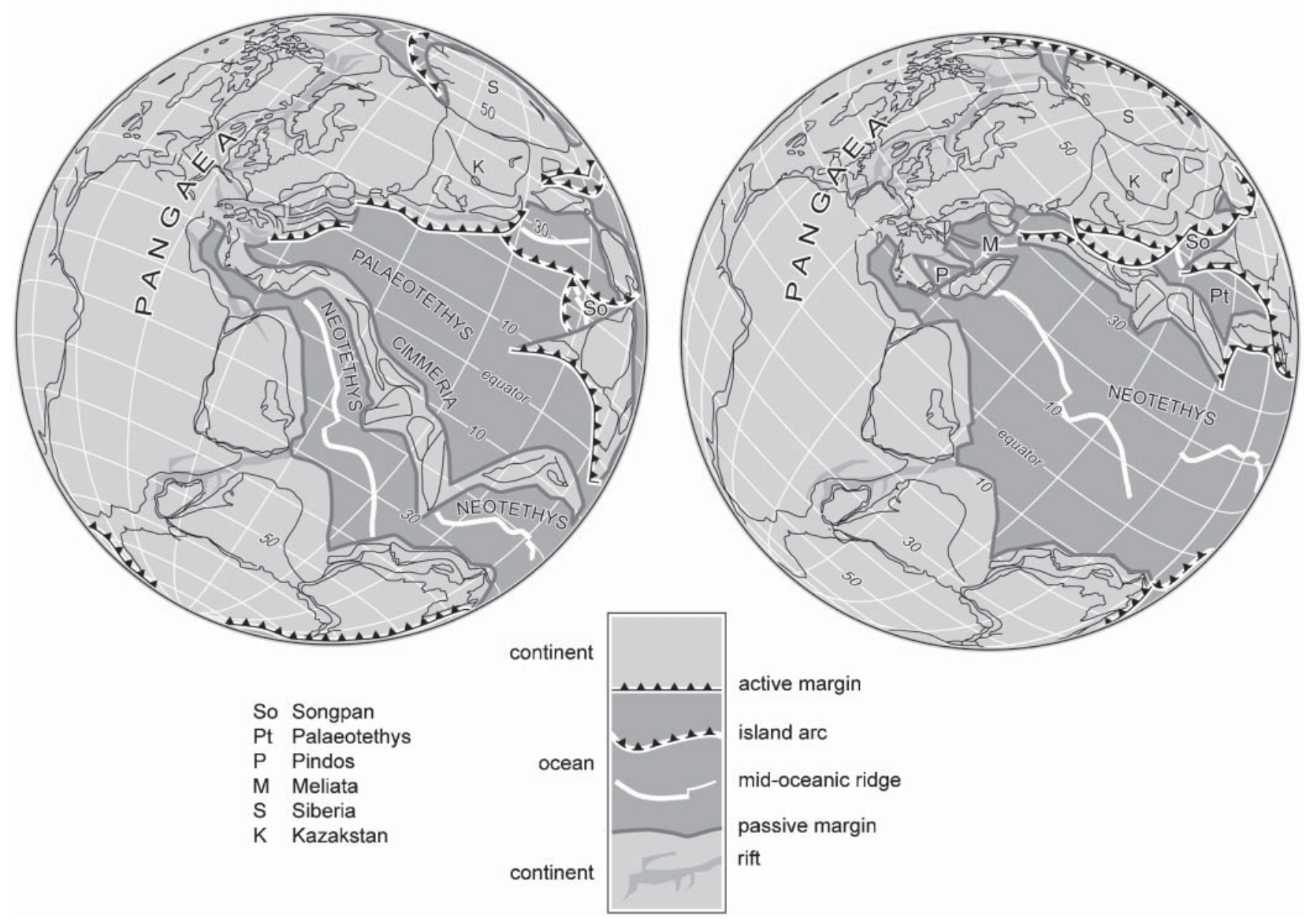

Early Norian

Fig. 13.1. Plate tectonic reconstruction for the Tethys region for the Permian-Triassic boundary and the early Norian. Modified from Stampfli \& Borel (2002).

successions can be broadly divided into a Lower Triassic fluvial sandstone, red-bed dominated succession, overlain by a Middle and Upper Triassic succession that is dominated by mudstones, carbonates and evaporites. The extent to which this reflects palaeoclimatic or eustatic sea-level changes, end-Permian biotic recovery or regional changes in the tectonic stress regime is debatable (Ziegler 1990; Jacquin \& de Graciansky 1998; Benton $\&$ Twitchett 2003). The timing of this switch, at the transition from the Lower to Middle Triassic in the red-bed succession of central Europe, also coincides with changes in the depositional style in many Tethyan successions on the southern European Margin (Ruffer \& Zuhlke 1995; Gianolla \& Jacquin 1998). Central European areas that were adjacent to local clastic sources, such as the fringes of Fennoscandia, or the dissected fragments of the Variscan Mountains, may not show the same pattern and timing of changes.

In the Boreal Ocean to the north, widespread marine clastic sedimentation persisted on the extensive Arctic and Barents Sea shelves throughout the Permian into the Early and Mid Triassic (Fig. 13.2) (Doré 1991). Early and Mid Triassic marine sedimentation may have episodically extended southwards through the Norway-Greenland rift system (Doré 1991). In contrast to much of northern Europe, the Boreal Ocean experienced its major environmental change during the Late Triassic (Carnian), when extensive deltaic systems prograded over many marine basins, which had existed for much of the preceding Permian and Triassic (Doré 1991; Skjold et al. 1998).
The red-bed Triassic successions in Europe were characteristically deposited in graben and extensional basins, with a variety of orientations, which may reflect both underlying basement structures and regional stress fields (Fig. 13.2) (Peacock 2004). The relative timing of basin formation and filling was quite variable. Locally an Early Triassic formation and filling-phase occurred in areas such as the Irish and Scottish Atlantic margins and northern North Sea. Major extension does not appear to have taken place in many European areas until Mid or Late Triassic times (Zeigler 1990), as in many graben systems in North Africa and the eastern seaboard of North America.

The last stage of the Triassic (the Rhaetian) witnessed marine flooding of many of the continental basins of Europe, with the exception of some in Eastern Europe and those fringing Fennoscandia. This pre-empted the marine connection of the Tethys and Boreal Oceans in the Jurassic through the Greenland-Norway rift system.

\section{Triassic stratigraphy}

The Triassic, as originally proposed by Friedrich August von Alberti in 1834, comprised three lithostratigraphic subdivisions based on the German succession, the Bunter, Muschelkalk and Keuper. The Triassic Period is now subdivided into seven stages (Induan, Olenekian, Anisian, Ladinian, Carnian, Norian and 


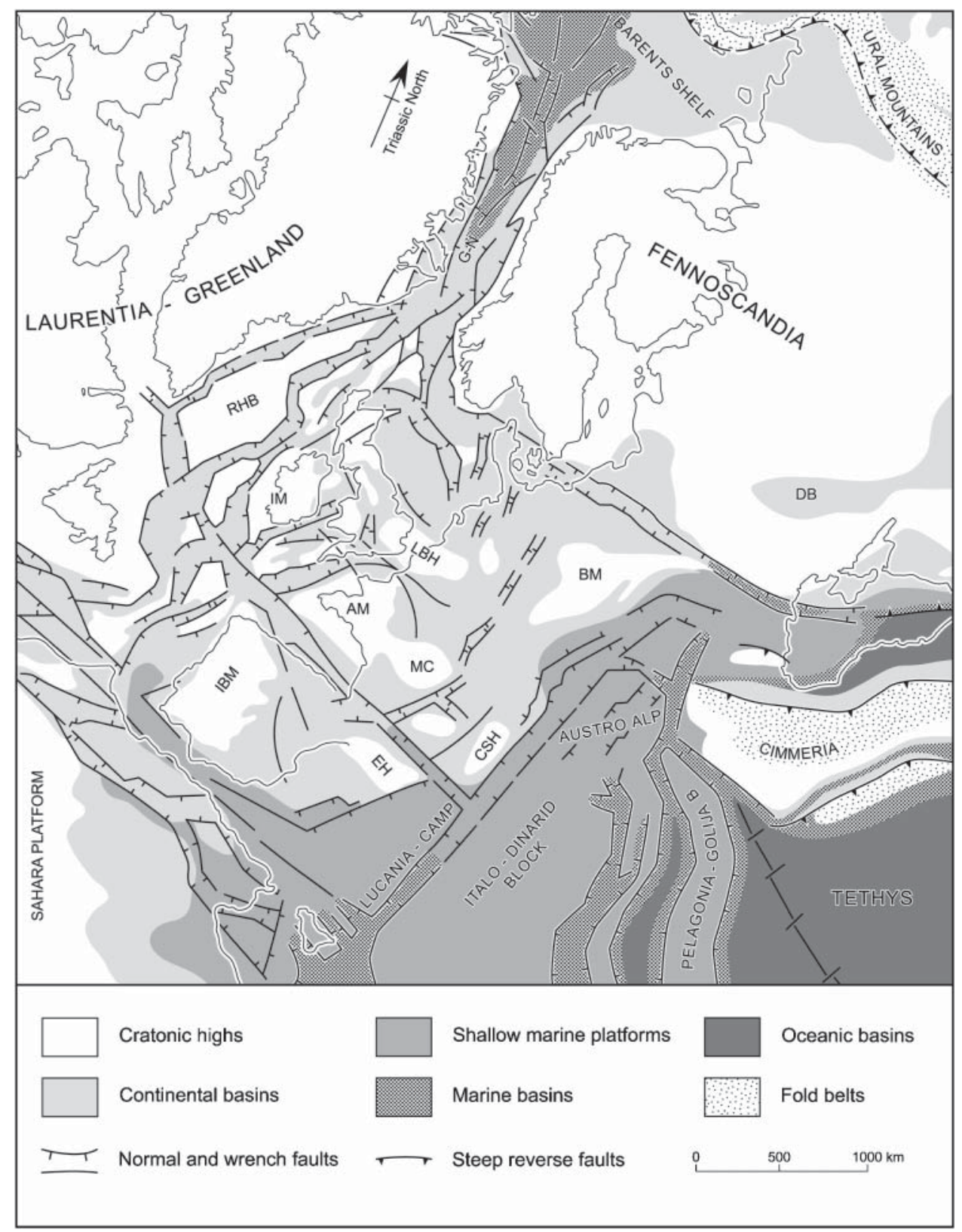

Fig. 13.2. Triassic basins and palaeogeography of Europe and the North Atlantic region in the Lower Triassic. Major rift basins are also indicated with fault ornament. Major 'upland' areas are AM, Armorican Massif; BM, Bohemian Massif; CSH, Corsica-Sardinia High; EH, Ebro High; IBM, Iberian Mesata; IM, Irish Massif; LBH, London-Brabant High; MC, Massif Central High; RHB, Rockall-Hatton Bank. Basins areas are: DB, Donetz Basin; G-N, Greenland-Norwegian rift. Modified from Ziegler (1990).

Rhaetian). Chronostratigraphic division of the Triassic succession in England and Wales is made problematic by the rarity of fossils, hence the British onshore Triassic is broadly divided into three lithostratigraphic units, the Sherwood Sandstone Group, the Mercia Mudstone Group and the Penarth Group (Figs 13.3 $\&$ 13.4). In this work we have used a subdivision of these groups based on the schemes of Warrington et al. (1980), Ritchie et al. (1996) and Howard et al. (2006), which attempt to define a UK wide system of formation subdivision, which is still in the process of refinement (Figs 13.3, 13.4).

Significant advances have begun to resolve some of the correlation and dating problems in the Triassic. Palynologists using fossil spore and pollen assemblages have begun to give sometimes broad and occasionally precise chronostratigraphic definitions, through links to section-based studies, outside the UK, that have ammonite or conodont-dated successions.
(Warrington 1996). The use of borehole sonic and gammaray $\log$ signatures in the subsurface has also substantially improved lithostratigraphic schemes and intra-basin correlation (Lott et al. 1982; Howard et al. 2006). The use of magnetostratigraphy in the next decades holds the promise of providing a more precise chronostratigraphy, at the substage level (or better) for much of the unfossiliferous and poorly dated British Triassic (Hounslow \& McIntosh 2003; Hounslow et al. 2004).

Defining the base of the Triassic in England and Wales has proved problematic in many areas, in that at best a succession of unfossiliferous red-beds marks the transition from the fossiliferous Zechstein into the Triassic. Magnetostratigraphic and biostratigraphic work in Germany accurately places the Permian-Triassic boundary there within the lowest part of the Calvörde Formation (Lower Buntsandstein; Szurlies et al. 


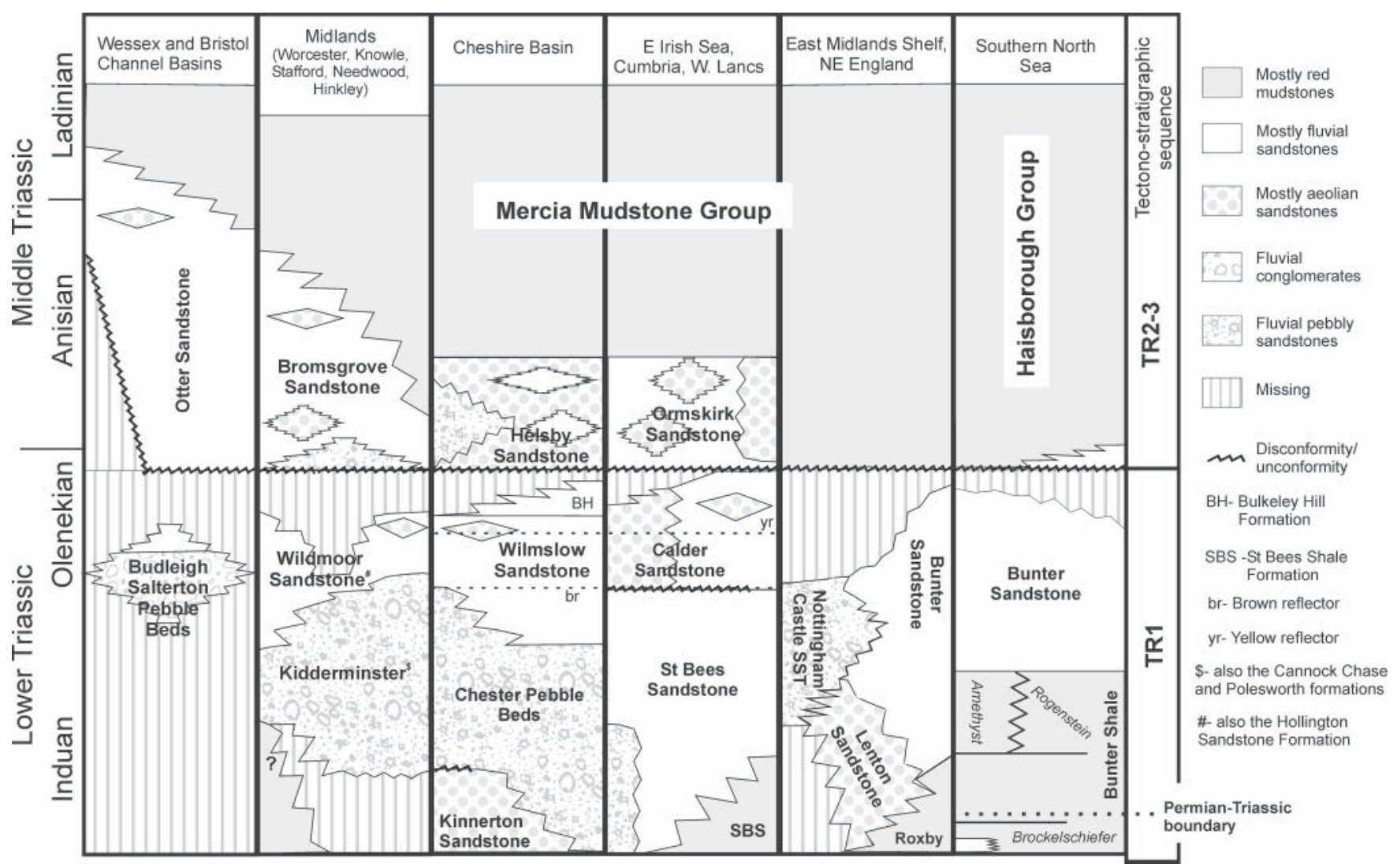

Fig. 13.3. Stratigraphy of the Sherwood Sandstone Group in England and Wales. In the southern North Sea the Bunter Sandstone and Shale comprise the Bacton Group. Based on Warrington et al. (1980, 1999), Cameron et al. (1992), Barnes et al. (1994), Jackson et al. (1995), Ritchie et al. (1996) and Rees \& Wilson (1998).

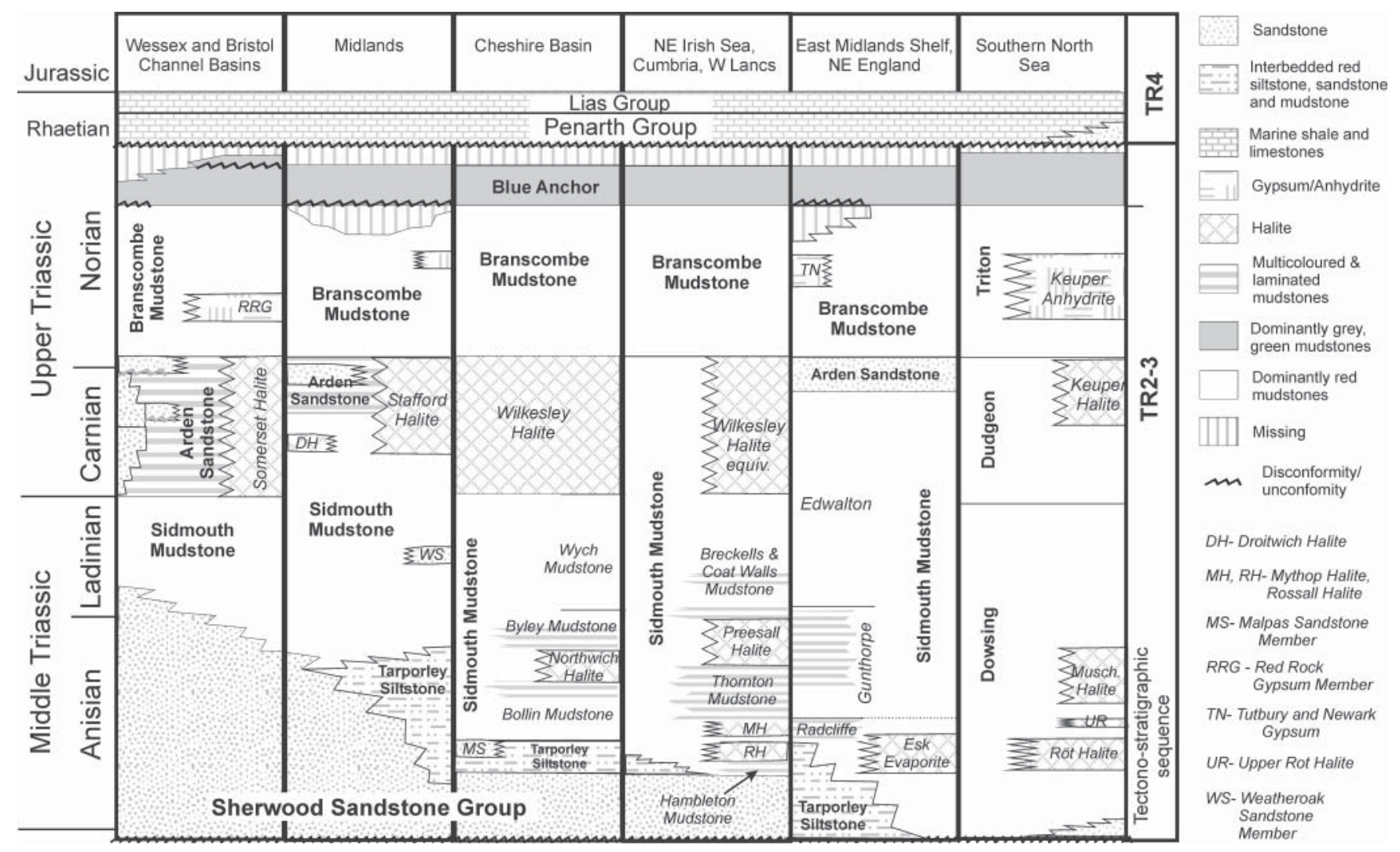

Fig. 13.4. Stratigraphy of the Middle and Upper Triassic in England and Wales. Based on Old et al. (1991), Cameron et al. (1992), Richie et al. (1996), Barclay et al. (1997) and Howard et al. (2006). 
2003). Based on geophysical log correlation, this equates in the Dutch southern North Sea to cycle 5 of the Lower Buntsandstein - a level near the base of the UK offshore Bunter Shale Formation (part of the Bacton Group; Fig. 13.3), a short distance above the Bröckelschiefer Member (Cameron et al. 1992). This is a level that can also be recognized locally in the East Irish Sea Basin (Jackson et al. 1995). In other areas major changes in lithology or well-log response, which mark the base of the Sherwood Sandstone Group, have been chosen arbitrarily (Fig. 13.3).

\section{Triassic palaeontology}

The Triassic witnessed the lowest diversity of invertebrate families since the Cambrian, a reflection of the slow recovery rate of biota after the massive extinctions of the Late Permian (Chapter 12). In the UK the first major evidence of the new Mesozoic flora and faunas occurred during the Anisian (Bromsgrove Sandstone Formation, etc.). Punctuated extinctions appear to have characterized the Late Triassic, even though there is scant evidence of this in the British Triassic (Benton et al. 2002; Benton \& Twitchett 2003). These Late Triassic extinctions, which include the extinctions at the Triassic-Jurassic boundary, globally show a larger loss of invertebrate families than that produced at the end of the Mesozoic (Hallam 2002; Tanner et al. 2004).
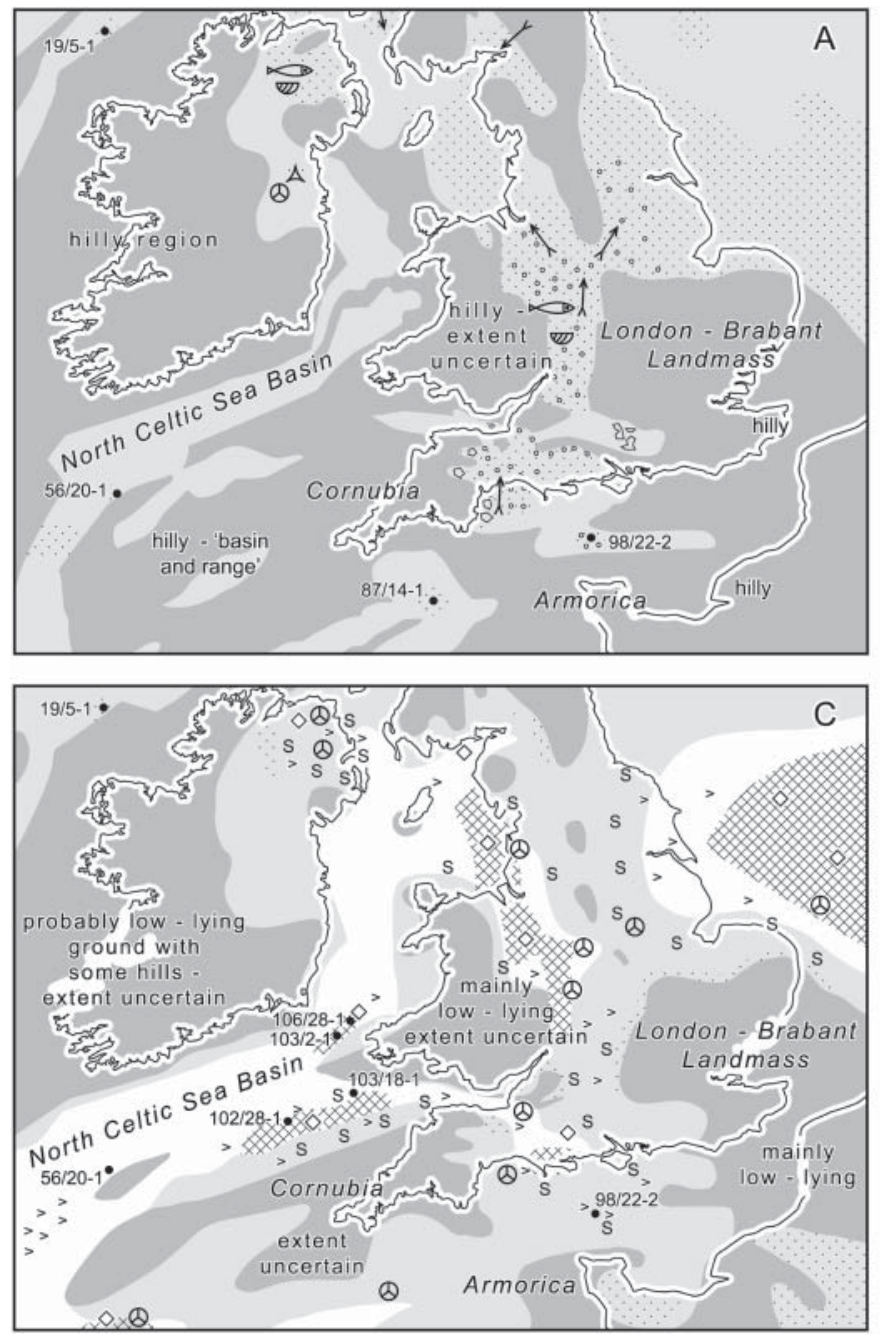

\section{Early-Mid Triassic palaeontology}

The Lower Triassic units of the Sherwood Sandstone Group are largely devoid of significant fossils, except for rare insects and invertebrates trace fossils, vertebrate footprints, conchostracans, (crustaceans), and a single fish (King \& Benton 1996; Powell et al. 2000b) (Fig. 13.5a). Some of these records of vertebrate tracks have been discounted by King \& Benton (1996) as inorganic structures. It is not until the Anisian age units of the Sherwood Sandstone Group that significant numbers of fossils are found in the UK (Fig. 13.5b). The reasons for this may be twofold. First, the biotic recovery from the end-Permian extinctions appears to have been slow, and diversity probably did not recover to Late Permian levels until the Mid Triassic (Erwin et al. 2002; Benton \& Twitchett 2003). Secondly, fluvial systems which dominate the Early Triassic across many European basinal areas was not a good environment for fossil preservation.

The Otter Sandstone Formation (Wessex Basin), Bromsgrove Sandstone Formation (Midlands) and the Helsby Sandstone Formation (Cheshire Basin) all contain tetrapod remains and associated trace fossils (Benton 1997; Warrington et al. 1999). These faunas are dominated by reptilian (rhynchosaur) remains and include two or three types of temnospondyl amphibians as well as fish species (Milner et al. 1990; Benton 1997; Spenser \& Storrs 2002). Footprints left by tetrapods occur in Cheshire (e.g. the Helsby Sandstone) and in other units of Anisian age (Benton et al. 1994; Benton \& Spenser
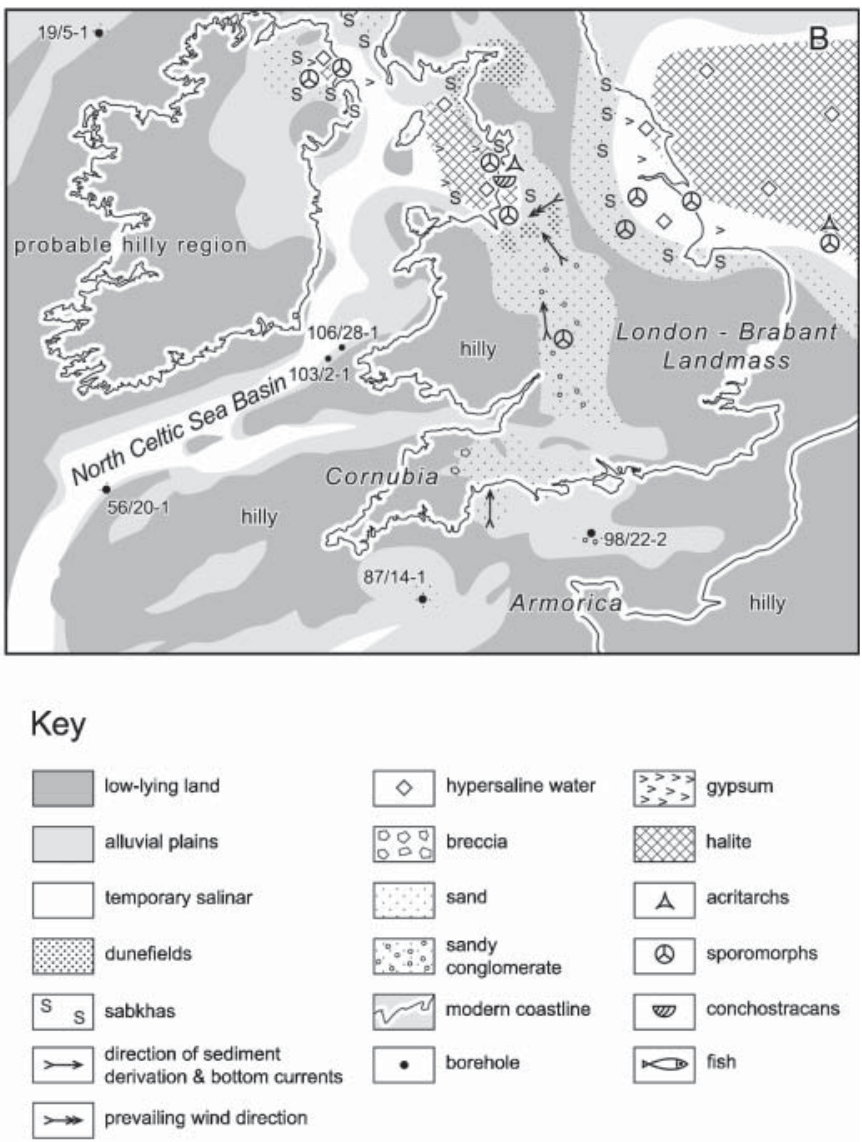

Fig. 13.5. Palaeogeography and palaeoenvironments during: (a) Early Triassic (Kidderminster Formation and equivalents); (b) early Anisian (Röt Halite Member and equivalents); (c) Carnian (Keuper Halite Member and equivalents). Modified from Warrington \& Ivimey-Cook (1992). 
1995). Micro- and macrofloral remains are common to rare in interpreted flood-plain deposits of meandering river systems. These include equisetalean plants of damp environments and conifers of dryer environments. The microfloral remains suggest dominance by gymnosperms, principally conifers, along with cycadalean and ginkgoalean components (Warrington \& Ivimey-Cook 1992). Other fossils known from these and adjacent units are conchostracans (Fig. 13.7b), a scorpion, a single Mytilus (Wills 1970) and ostracods (Old et al. 1991; Warrington \& Ivimey-Cook 1992). Equivalent basinal facies are largely devoid of fossils except for rare intervals of landderived miospores. The Tarporley Siltstone Formation (Fig. 13.4) in Cheshire contains plant remains, inarticulate brachiopods (Lingula) and, rarely, Rhynchosaurus sp. tetrapods (Warrington et al. 1980).

\section{Late Triassic palaeontology}

Within the Mercia Mudstone Group two formations stand out as being particularly important for containing fossils, the Arden Sandstone Formation and the Blue Anchor Formation (Fig. 13.4). Other units are generally barren except for rare Botryococcus and Plaesiodictyon (green algae) fragments found in some units (Talbot et al. 1994; Barclay et al. 1997), and some land-derived spore and pollen-rich intervals (Warrington \& Ivimey-Cook 1992; Barclay et al. 1997). Land vertebrates were present, evident by tracks left behind in environments marginal to the red mudstones in South Wales (Tucker \& Burchette 1977).

The Carnian Arden Sandstone Formation and equivalent intervals have yielded plant megafossils (stems, fructifications), and miospores indicating bryophytes, sphenopsids and pteropsids (Old et al. 1991). The fauna includes possibly marine bivalves (Nucula?, Pholadomya?), conchostracans (Euestheria) and shark (teeth) remains (Old et al. 1991). Land vertebrates are represented by labyrinthodont amphibians and rhynchosauroid remains, along with vertebrate tracks. Soft-bodied organisms were also widespread, evident by a rich diversity of trace fossils (Fig. 13.7d) (Old et al. 1991; Barclay et al. 1997). Reworked fossil material may occurs at the base of the sandstones in the Arden Sandstone Formation, as abraded and concentrated vertebrate material (Ruffell 1991).

In the British Triassic, the Penarth Group contains the most diverse macro- and microfossils. Consequently it has attracted a long history of study, much of it described in detail in Swift \& Martill (1999) and Benton et al. (2002).

The palynological (terrestrial spore and pollen) records from the upper part of the Branscombe Mudstone Formation, through the Blue Anchor Formation to the latest Triassic in the basal parts of the Lias Group have been intensively studied at many sections and boreholes in England and Wales (Warrington \& Whittaker 1984; Waters \& Lawrence 1987; Warrington \& Ivimey-Cook 1995; Edwards 1999). Where these records appear to be complete, such as in north Somerset and South Wales, the spore and pollen diversity increases from the Branscombe Mudstone Formation, through the Blue Anchor Formation into the upper part of the Penarth Group. Many of the taxa that contribute to this diversification are species of trilete spore genera. Most of the common taxa range upwards through the Blue Anchor Formation, into the Penarth Group and in some cases, into the Lias Group. An abrupt reduction in microfloral diversity occurs in the uppermost parts of the Penarth Group and into the lowermost Lias Group. Above this level, miospore diversity is much lower, a feature which persists well into the Lower Jurassic. This decrease in diversity is also reflected in the bivalves, since the Penarth Group bivalve assemblages are distinct from the lower diversity assemblages that characterize the pre-planorbis parts of the Lias Group (Whittaker 1978). One of the key, stratigraphically useful, microfossils of this interval is the dinoflagellate cyst Rhaetogonyaulax rhaetica, which ranges from the higher part of the Blue
Anchor Formation into the lowest part of the Lias Group, and which allows correlation to unequivocal Rhaetian strata elsewhere in Europe (Warrington \& Ivimey-Cook 1995; Swift 1999). Conodonts, which became extinct prior to the Jurassic, are typically recovered from the upper parts of the Penarth Group and in some areas from the Pre-Planorbis Beds of the Lias Group (Swift 1995a).

\section{Tectono-stratigraphic sequences}

Within England and Wales the Triassic can be divided into three first-order tectono-stratigraphic sequences, each bounded at the base by a major regional unconformity, overlain by a transgressive succession which may overstep onto older rocks (Figs $13.3 \& 13.4$ ). The sequence naming utilizes that used in the European-wide regional synthesis by Gianolla \& Jacquin (1998). In the case of the British Triassic the unconformities bounding the first-order sequences also separate sedimentary successions that display major differences in environmental conditions.

Sequence TR1. The lower boundary in basinal areas separates the Permian Zechstein from the overlying units of the Sherwood Sandstone Group. Within the southern North Sea the base of this sequence is the base of the Bacton Group, which may show a conformable contact with the underlying Zechstein Group (Fig. 13.3). In the East Irish Sea Basin away from basin margins, the base of TR1 may be within the St Bees Shale. Within many non-basinal areas the base of sequence TR 1 corresponds with the locally unconformable base of the Sherwood Sandstone Group which may overstep onto older rocks. Disconformities within this sequence are known in the East Irish Sea Basin at the base of the Calder Sandstone Formation (Barnes et al. 1994), and in the succession on the eastern margin of the UK southern North Sea, where unconformities in the German and Dutch Lower Triassic can be traced into UK waters using wire-line logs (Geluk 2005a, b).

Sequence TR2-3. The Sherwood Sandstone Group in western and SW Britain is divided by the unconformable base of sequence TR2-3 (Fig. 13.3). In eastern England (east of Charnwood) and the southern North Sea this unconformity lies either at or slightly below the base of the Mercia Mudstone Group (or Haisborough Group offshore; Cameron et al. 1992; Geluk \& Röhling 1999). This unconformity is equivalent to the Hardegsen unconformity (H-unconformity) of the Dutch and central European basins (Wills 1970; Holloway et al. 1989; Cameron et al. 1992; Geluk 2005b). The age of the H-unconformity in the German basin is thought to be late Olenekian (latest Early Triassic; Gianolla \& Jacquin 1998; Kozur 1999). In some UK areas such as the East Irish Sea Basin, the base of TR2-3 is rather more disconformable than unconformable (Jackson et al. 1995). In basins adjacent to the East Irish Sea, this unconformity has been difficult to identify, leading some workers to deny its existence in these areas (Meadows pers comm. 2000). However, onshore basins, such as those in the Midlands and the Cheshire Basin, indicate the unconformable nature of the base of TR2-3. This unconformity is here referred to as the $\mathrm{H}$-unconformity. One or more other disconformities or unconformities within TR2-3 may have regional significance in England and Wales, to subdivide the sequence. Workers in other European basins subdivide this sequence into separate sequences TR2 and TR 3 with a boundary either in the late Ladinian or early Carnian (Gianolla \& Jacquin 1998). The significance of a major unconformity or disconformity at this level in the UK is unproven, but may correspond to a level within the Arden Sandstone Formation at the base of one or more of the sandstone units (Fig. 13.4) (Ruffell \& Shelton 1999). A better case can be made for a regional disconformity at the base of the Blue Anchor Formation (see below). 
In the Dutch sector of the southern North Sea the early Kimmerian I unconformity occurs above the Red Keuper Evaporite Member (Geluk 2005b; equivalent to the Keuper Anhydrite Formation of the Triton Formation), which is currently unrecognized in the UK onshore. Future work will probably allow a subdivision of TR $2-3$ to be established in the UK.

Sequence TR4. The base of the Penarth Group locally forms an unconformity, or locally disconformable boundary, with a substantial part of the underlying beds removed by erosion (Fig. 13.4) (Mayall 1981; Hounslow et al. 2004). The equivalent of the Penarth Group in the southern North Sea and Germany, the Sleen and Exter formations of the Dutch and German sectors respectively, are separated from underlying units by the Kimmerian II unconformity of Ziegler (1990) and Geluk (2005b) and the equivalent early Cimmerian unconformity of Jacquin \& de Graciansky (1998). Sequence TR4 extends into the Middle Jurassic as the 'Ligurian cycle' of Jacquin \& de Graciansky (1998). In the England and Wales the Triassic part may be subdivided by a disconformity within the upper part of the Penarth Group (Hesselbo et al. 2004).

Tectono-stratigraphic sequence TR 1 shows the largest regional differences in lithostratigraphic terminology and lithology (Fig. 13.3), reflecting the fact that separate basins had to a large extent separate sedimentation histories. This regional variation in geology is progressively lost in younger strata upwards through sequence TR2-3 (Fig. 13.4), such that by the time of deposition of the Blue Anchor Formation major regional differences are limited. For this reason the regional differences in the Triassic below the Blue Anchor Formation are discussed in separate regional sections below, while the Blue Anchor Formation and Penarth Group are discussed in a single section each.

\section{Triassic environments in the Sherwood Sandstone Group}

\section{Within sequence TR1}

Where the base of the Triassic can be located confidently (such as in the southern North Sea and East Irish Sea basins), fluvial sandstone-dominated units overlie a mudstone dominated unit in the lower parts of the British Lower Triassic (Fig. 13.3). These sandstones show northwards directed palaeocurrents (Fig. 13.5a) (Cameron et al. 1992; Jones \& Ambrose 1994). Within the onshore basins (where the Permian-Triassic boundary can be less confidently located) the fluvial sandstones below the H-unconformity are dominated by evidence of a river system, which Wills (1956) termed the 'Budleighensis' river system (Fig. 13.5a). Within the western onshore basins this river system seems to have been one which was sourced from the Variscan uplands of Brittany and the southern English Channel (possibly also Iberia), and then flowed northwards through the Wessex Basin, through the Worcester Basin, the Midland basins (Knowle, Needwood, Stafford, Cheshire) and on into the East Irish Sea Basin (Figs 13.5a \& 13.6). A distributary branch perhaps flowed periodically eastwards onto the East Midlands Shelf through the Charnwood Gap. Evidence for the generally northwards directed palaeocurrents in the Midland basins (Steel \& Thompson 1983; Chisholm et al. 1988; Rees \& Wilson 1998 ) is reinforced by the general southerly source of pebbles and heavy minerals (Fig. 13.5a) (Thomas 1909; Cocks 1993).

Within the Midlands these deposits are dominated by pebbly sandstones and conglomerates (Fig. 13.3), which have been interpreted as the deposits of a braided river, flowing within well-confined channels (Steel \& Thompson 1983). This river system probably had large seasonal changes in discharge, evident by cross-stratified sandstones deposited at stages of lower flow, although it is perhaps doubtful if this system was ephemeral in nature (Smith 1990) for there is little evidence of interbedded aeolian sandstones in basinal settings (Rees \& Wilson 1998). However, at basin margins in Cheshire and the East Midlands the oldest units of the Triassic are predominantly aeolian sandstones, whose deposition perhaps extended uninterrupted from the Permian. These are the Kinnerton Sandstone Formation (and Permian Collyhurst Sandstone Formation) in Cheshire and the Lenton Sandstone Formation (in part Permian) in the East Midlands (Fig. 13.3), which interdigitate laterally with fluvial sandstones and red playa mudstones.

Within each of the basins it is clear that locally sourced material was also an important component of the fluvial systems (Chisholm et al. 1988; Rees \& Wilson 1998; Smith \& Edwards 1991), indicating drainage relief at the basin margins. However, Triassic palaeovalleys have been recognized at only a few locations (Taylor 1968; Chisholm et al. 1988; Worssam \& Old 1988), although these must have been relatively common features in the Early Triassic landscape before being erased by later events. These pebbly-sandstone deposits pass upwards into finer-grained sandstones with mudstone intervals (e.g. Wildmoor and Wilmslow Sandstone formations), indicating the upwards transition from braided to meandering river systems.

In the more northerly basins (East Irish Sea, Solway Firth and Vale of Eden basins; Fig. 13.6) Early Triassic river systems were sand dominated, evidence of the lower flow regime of the river system (Fig. 13.5) (Brookfield 2004). Stacked channel sandstones formed predominantly in a low sinuosity sandybraided river system (Jones \& Ambrose 1994) with local evidence of aeolian, sand-sheet and playa-type environments (Meadows \& Beach 1993; Brookfield 2004). The aeolianderived component may increase upwards until it forms the major component in some basin-margin situations, such as in West Cumbria (Jones \& Ambrose 1994). The Budleighensis river system may have terminated in the East Irish Sea or Solway Firth basins as a series of continental playa basins, or perhaps more likely flowed westwards or northwards towards the present-day proto Atlantic rift.

\section{Within sequence TR2-3}

The 'Budleighensis' river system continued to flow northwards through the Wessex and Midlands basins, evident by palaeocurrent trends (Henson 1972; Ireland et al. 1978; Meadows \& Beach 1993; Powell et al. 2000b; Svendson \& Hartley 2001), but the depositional style radically changed, to fluvial sandstone dominated in the southern UK and Midlands basins, to aeoliansandstone dominated in the NW England basins (Fig. 13.5b). This shift was perhaps a consequence of a major reduction in the gradient of the Budleighensis river system. The Otter Sandstone and Bromsgrove Sandstone formations of the southern basins are mostly stacked channel sandstones, formed in sinuous or straight channelled river systems, which produced copious amounts of intraclastic debris, both from pedogenic carbonates and erosion of overbank mudstones (Old et al. 1991). The abundance of pedogenic carbonates in these Anisian sandstones indicates that stable landscape surfaces (i.e. soils) were able to develop. Also for the first time in the British Triassic, significant faunal and floral elements are found including plants, invertebrates, arthropods, fishes and reptiles, all evidence of a fluvial landscape punctuated by lakes and plant growth more extensive than in the Early Triassic (Purvis \& Wright 1991; Benton \& Spenser 1995; Spenser \& Storrs 2002). River systems from locally derived sources remained important at basin margins, as indicated by locally sourced breccias and conglomerates forming the major part of some fluvial successions (Fig. 13.5b) (Barclay et al. 1997; Bridge et al. 1998).

In the northern basins (Fig. 13.6; Cheshire, East Irish Sea, Vale of Eden basins) an interfingering succession of fluvial channel sandstones and aeolian sandstones dominate the succession. Fluvial systems in the East Irish Sea Basin were 


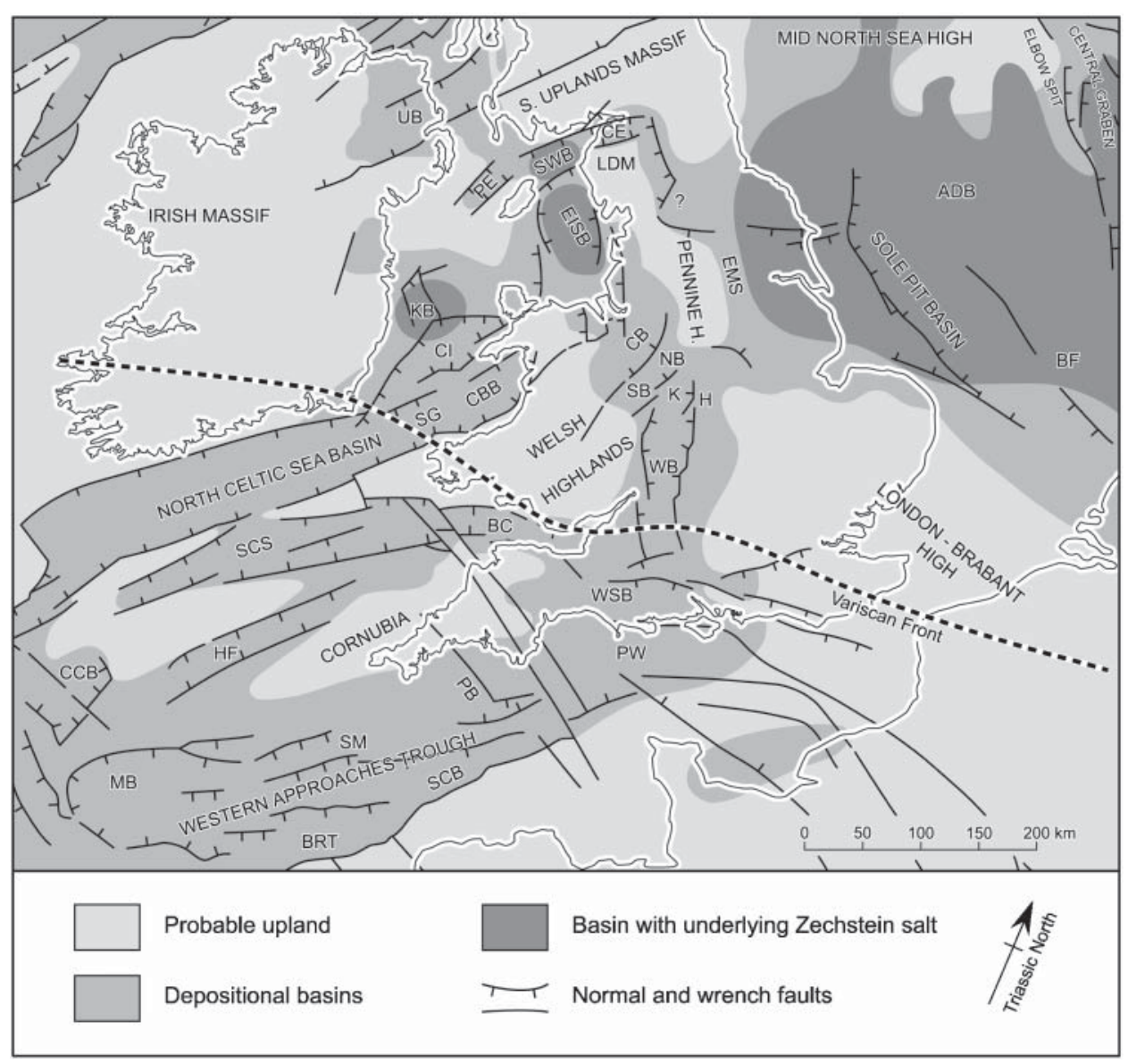

Fig. 13.6. Important Triassic basins and highs of England and Wales. Basins: ADB, Anglo Dutch; BC, Bristol Channel; BRT, Britanny Basin; CB, Cheshire; CBB, Cardigan Bay; CCB, Cockburn CE, Carlisle/Vale of Eden; CI, Central Irish Sea; EISB, East Irish Sea; EMS, East Midlands Shelf; H, Hinkley; HF, Haig Frais; K, Knowle; NB, Needwood; KB, Kish Bank Basin; MB, Melville; PB, Plymouth Bay; PE, Peel; PW, PortlandWight; SB, Stafford; SCB, South West English Channel; SCS, South Celtic Sea; SG, St Georges'; SM, St Mary's; SWB, Solway Firth; UB, Ulster; WB, Worcester; WSB, Wessex. Faults and highs: BF, British Forties High; LDM, Lake District Massif.

located adjacent to bounding faults, indicating contemporaneous fault activity (Meadows \& Beach 1993; Holliday et al. 2004). At the basin margin in west Cumbria, the river channels flowed into the East Irish Sea Basin in a WSW direction either due to control by wind-aligned linear dune systems or due to the local palaeoslope (Jones \& Ambrose 1994). These channels formed part of large low gradient sand-flat systems, which flooded seasonally and strongly controlled the geometry of the aeolian bedforms both within the East Irish Sea Basin and farther south in the Cheshire Basin (Goodall et al. 2000; Mountney \& Thompson 2002). These aeolian sand seas seem to have been most prevalent in basin margin locations such as those fringing the Lake District (Arthurton et al. 1978; Brookfield 2004).

\section{Triassic environments in the Mercia Mudstone Group}

The transitional interval between the sandstone-dominated Sherwood Sandstone Group and the mudstone-dominated Mercia Mudstone Group has always posed problems for subdivision and interpretation. In the older literature this transitional interval is occupied by the 'waterstones' in the Midlands and NW England (Wills 1970) but has been more recently assigned to the Tarporley Siltstone Formation and grouped with the Mercia Mudstone Group (Howard et al. 2006). This interval is characterized by interbedded red mudstones/siltstones and finegrained sandstones, in approximately equal proportions, locally with high abundances of mica on bedding planes. It typically has numerous well preserved sedimentary structures, including laminations, ripples, mudcracks, slumping, gypsum nodules, salt psuedomorphs and invertebrate trace fossils (Elliot 1961; Wills 1970; Ireland et al. 1978). Ireland et al. (1978) interpreted the Tarporley Siltstone Formation of the Cheshire Basin as 'intertidal', although it probably represents the deposits of a lake-margin with interdigitation of fluvial sheet-floods and a playa-mudflat system. The transitional lithologies are diachronous (Fig. 13.4), and have been locally assigned to either the Mercia Mudstone or the Sherwood Sandstone (Old et al. 1987; Barclay et al. 1997; Powell et al. 2000b; Hounslow \& McIntosh 2003; Gallois 2004).

\section{The 'red' mudstones}

During the Mid-Late Triassic extensive successions of predominantly red mudstones developed in England and other parts of NW Europe. There are broadly three types of mudstone facies present.

Blocky mudstones (Fig. 13.7a). These are calcareous and dolomitic silty mudstones, which commonly weather at outcrop to small blocks up to several $\mathrm{cm}$ in size (Arthurton 1980). They are predominantly dark-pale brownish red in colour, although pale grey-dark greenish grey mudstones are also not uncommon. The grey and grey-green coloured blocky mudstones are dominant in the Arden Sandstone Formation and the Blue Anchor Formation. The mudstones are a mixture of quartz silt, clay, 


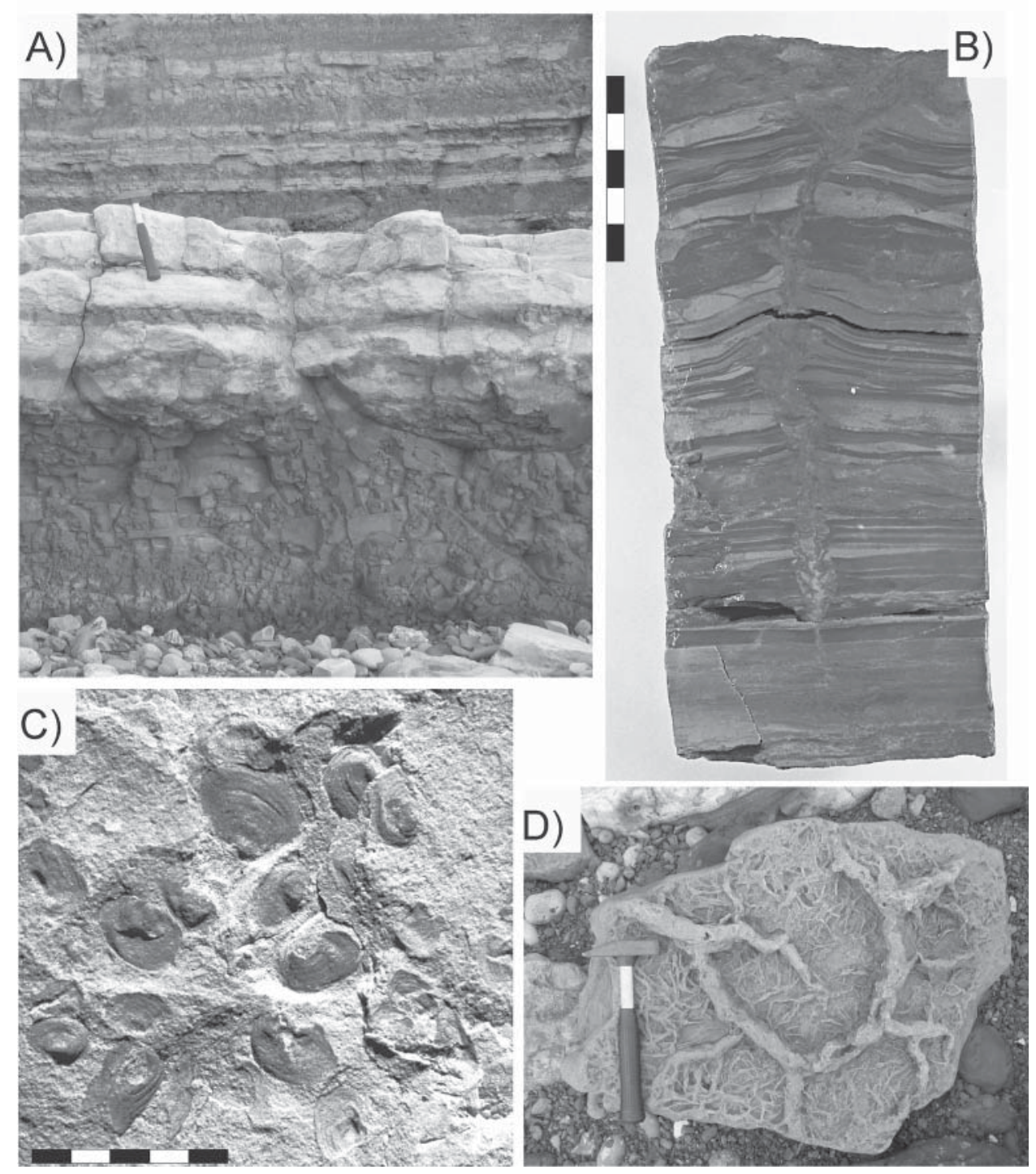

Fig. 13.7. (a) Pale carbonate-rich beds (bed A11 of Whittaker \& Green 1983) interbedded with blocky-fracturing red and green mudstones. Branscombe Mudstone Formation, St Audries Bay, North Somerset. (b) Laminated siltstone-mudstones couplets, showing evidence of poorly preserved ripples, bisected by a large vertical desiccation crack (Thornton Mudstone Member, Churchtown borehole, Lancashire, $108 \mathrm{~m}$ ).

(c) Conchostracans (crustaceans - Euestheria minuta), from Cycle F of the Thornton Mudstone Member, Churchtown Borehole, depth $122.8 \mathrm{~m}$. (d) Large reticular mudcracks with smaller intervening burrows of trace fossil Fuersichnus (?) on the base of a fallen sandstone bed from the Arden Sandstone Formation, Hook Ebb, South Devon. Photographs (b) and (c) reproduced by permission of the British Geological Survey, CNERC, IPR/53-43c, all rights reserved. Photographs (a) and (d) courtesy of Richard Porter. Hammer $25 \mathrm{~cm}$ in length for scale in (a) and (d). Photograph (b) scale in $\mathrm{cm}$, photograph (c) scale in $\mathrm{mm}$.

dolomite and locally calcite, often with a few well-rounded scattered aeolian sand grains. Rarely do the blocky mudstones contain macrostructures, which can be easily observed at outcrop, other than cyclical variations in the size of the blocks the mudstones break into. The blocks commonly develop in weathered outcrops, and may in part be due to dissolution of variable amounts of evaporite or carbonate minerals. However, on sectioned surfaces, the mudstones may contain millimetreor submillimetre-scale structures which may be evident by small changes in clay/silt or carbonate content. These sedimentary structures can be broadly classified into two end-member groups. Firstly there is a more common group of structures of branching clay films with wispy or ghost-like vague laminae. Microstructures include blocky structure (peds), clay coatings on coarser grains and former voids (Wilson 1990, 1993; Talbot et al. 1994; Barclay et al. 1997). Secondly, some beds may show a variety of breccia-like fabrics. Elliot (1961) recognized two types of intraformational breccias, which he termed 'vein breccias' and 'flow-breccias'. His 'vein breccias' were mudstonefilled, near-vertical cracks or veins separating paler and larger angular mudstone blocks. These features probably represent extensive brecciation due to penetrating, multiple generation shrinkage (Barclay et al. 1997), although the vein-like features are somewhat reminiscent of clay cutans in palaeosols. Elliot's 'flow-breccias' display a range of structures, from relatively undeformed beds displaying slickensided listric surfaces, and microscale faulting to true breccias displaying horizontal arrangement of angular siltstone and mudstone fragments. These fabrics may represent palaeosols (vertisols) or the results of penecontemporaneous halite or gypsum dissolution (Barclay et al. 1997; Wilson 1990, 1993). In unweathered outcrops or cores the mudstone beds may contain gypsum veins, nodules or dispersed gypsum grains (Wilson \& Evans 1990; Talbot et al. 1994; Barclay et al. 1997). From the SW margin of the 

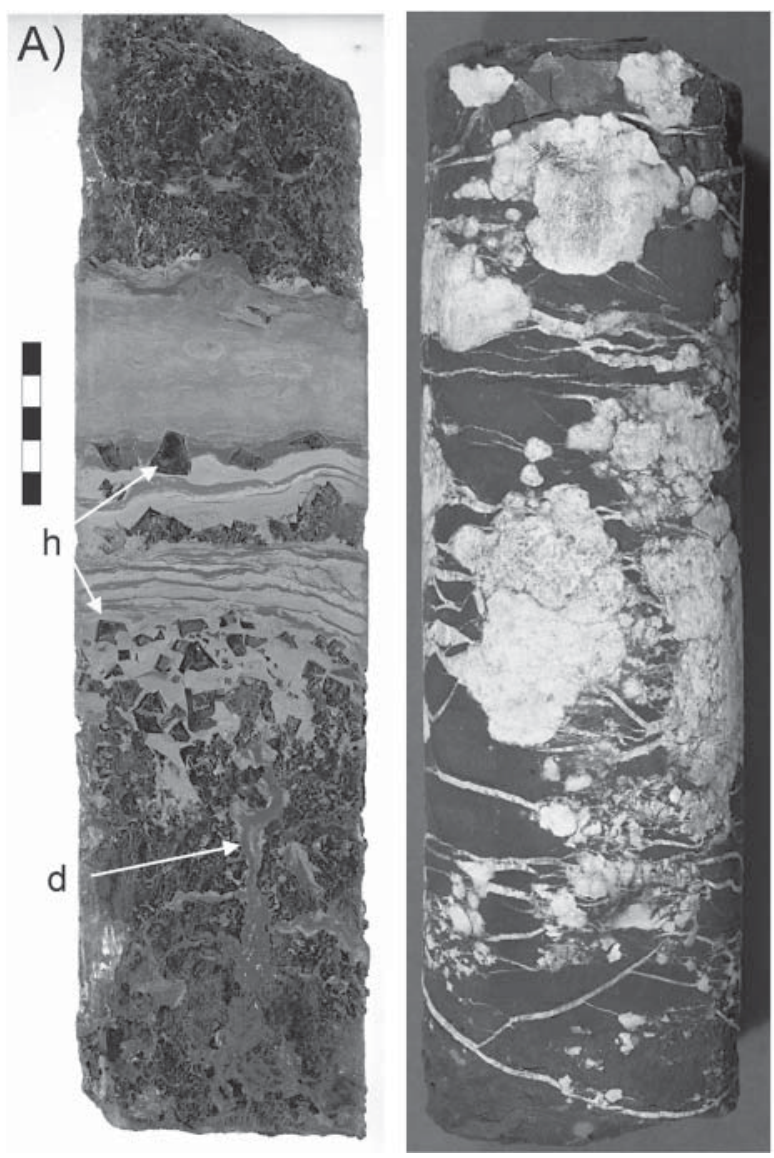

B)

Fig. 13.8. (a) Grey mudstone bed sandwiched between upper and lower halite beds (darker grey). The mudstone shows large halite crystals (h) due to in situ production (Haselgebirge halite). Note the vertical, red-mud-filled structures (desiccation crack (d) ?) within the lower halite bed. Mythop Halite Member, $301.3 \mathrm{~m}$ in Thornton Cleveleys borehole, Lancashire. (b) Nodular and vein gypsum within red mudstones (Breckells Mudstone Member. 147.2 m in Hacensall Hall borehole). Reproduced by permission of the British Geological Survey, CNERC, IPR/53-43c, all rights reserved.

Worcester Basin, Milroy (1998) has described a variety of features such as curvilinear slickensided planes, pseudo-anticlines, root traces, colour mottling and pedo-tubules, thought to be related to soil formation.

Laminated mudstones. These form a heterogeneous mudstone and siltstone facies characterized by siltstone (or sandstone) laminae, sometimes graded and up to $20 \mathrm{~cm}$ thick (Fig. 13.7b). The siltstones may be cross-laminated, and display current or wave-ripples, load structures, clay-breccias, small channellike structures or bioturbation (Klein 1962; Talbot et al. 1994; Wilson \& Evans 1990). The lamination may be distorted and broken by polygonal mud-crack networks, or slumping (Fig. 13.13). Psuedomorphs after anhydrite and halite were recorded by Arthurton (1980) and Wilson (1990). The colour varies from dark red to pale grey to dark grey and dark grey laminae may be pyrite bearing. This facies appears to be more common in basinal successions such as in the East Irish Sea, or Cheshire basins, where it may be interbedded with the blockymudstones (Fig. 13.13), but is also common in units approximately at the level of the Arden Sandstone Formation, or some areas flanking the southern North Sea (Plate 22).

Carbonate-rich mudstones. These are typically very pale greywhite beds, rich in calcite or dolomite (Fig. 13.7a). In many respects these are carbonate-rich variants of the laminated or blocky mudstone facies, displaying a similar range of macroscale sedimentary structures, including graded laminae, wave and current ripples, intraformational breccias, channel structures and mud cracks. In addition they may contain primary detrital carbonate grains such as pedogenic concretional carbonate and ooids (Talbot et al. 1994). This facies is not common, but is more typical of the upper part of the Mercia Mudstone Group, particularly the Blue Anchor Formation and parts of the Arden Sandstone Formation.

Both the laminated facies and the carbonate-rich facies that show abundant sedimentary structures, were probably formed in a shallow lacustrine environment. The waters of these lakes periodically dried up, shown by the common desiccation cracks (Arthurton 1980; Wilson \& Evans 1990; Talbot et al. 1994). The nearest modern analogue may be the Quaternary saline lakes of Australia (Rosen 1991; Talbot et al. 1994; Magee et al. 1995). The Mercia Mudstone carbonate facies possibly represents wetter climatic intervals than the clastic facies with the resulting lakes being either runoff-fed, or possibly groundwater fed (Talbot et al. 1994), producing brines of varying salinity (Taylor 1983).

\section{Environmental significance of blocky mudstones}

Opinions differ as to the depositional environment of the blocky mudstone facies; they have been interpreted as the deposits of distal alluvial playas (Tucker 1978; Talbot et al. 1994), permanent lakes or hypersaline epeiric seas (Wills 1970; Jeans 1978; Warrington et al. 1980) and soils (Milroy 1998). Talbot et al. (1994) addressed in detail the sedimentology of the red mudstones of the Branscombe Mudstone Formation in north Somerset, indicating that they lack the variety of sedimentary structures and lithofacies typical of Quaternary lacustrine deposits. Rather, a variety of microstructures including breccialike structures (peds?), clay coatings on coarser grains and former voids, branching clay films and wispy laminae, were interpreted as products of the soil environment. They envisaged that the red mudstones were formed on low-angle alluvial fans with the clay and silt transported in ephemeral rivers as mud aggregates, an environment comparable to that found in the Late Quaternary of east-central Australia (Magee et al. 1995). However, the alluvial input was probably supplemented and modified by major aeolian reworking, as is the case today in the Australian analogue (Dare-Edwards 1984; Jefferson et al. 2000). If this analogue were applied literally it would suggest that much of the clay and silt was transported into the basins as mud pellets via alluvial or aeolian transport (cf. Dare-Edwards 1984). Indeed, the aeolian origin of the blocky mudstones is a persistent interpretation from earlier studies (Lomas 1907; Wills 1970) that have suggested this facies is produced by dry deposition from dust storms, much like the Quaternary Australian parna deposits (Jefferson et al. 2000). The lack of preservation of macroscale structures, Talbot et al. (1994) suggested, was due to activity of plants and burrowing insects assisted by the development of efflorescent salt crusts (Smoot \& CastensSeidell 1994; Goodall et al. 2000) formed by contemporaneous precipitation of groundwater salts within the mudstones (Arthurton 1980). If these deposits were transported by water and wind as mud aggregates, the chances of preservation of sedimentary structures are indeed slim, and the size of the larger particles might provide a better guide to depositional particle size (Dare-Edwards 1984).

Macroscale sedimentary structures intercalated within the blocky mudstones, often on silty or sandy horizons, are dominated by wave-produced microripples, associated with thin intercalations of the laminated or carbonate facies, often heavily mudcracked (Klein 1962; Arthurton 1980; Wilson 1990, 1993; Wilson \& Evans 1990). In the marginal successions in South Wales and the Bristol region, the wave-dominated environment of some upper Mercia Mudstone deposits is indicated 
by wave cut-notches and lake-shoreline deposits (Tucker 1978; Milroy \& Wright 2000). These contrast with the mudstones described and interpreted by Milroy (1998) as displaying a strong pedogenic overprint. These and other successions such as those in NW England, suggest small-scale cyclicity in environmental conditions evident by interbedding of blocky and laminated mudstones (Fig. 13.13) (Arthurton 1980; Wilson 1990, 1993).

A single environmental interpretation for the blocky red mudstone units of the Mercia Mudstone Group is too simplistic, the environment probably fluctuated between periods of extensive saline-brackish lake systems to other times when the lakes were restricted to basin centres, and pedogenic processes and dust transport were widespread on the basin margins. The constant influences were probably long-distance aeolian transport of silt and clay (perhaps as aggregates, Dare-Edwards 1984; Jefferson et al. 2000), along with ephemeral alluvial redistribution of mud and silt by flash floods in a low gradient desert environment. The primary depositional process responsible is commonly concealed because of pervasive fabric disruption caused by efflorescent crusts, the burrowing activity of plants and animals, soil development and the original sediment transportation as mud aggregates.

\section{The evaporites}

These occur as beds of either gypsum-anhydrite or halite. Halite is present both as relatively pure layered halite $(<5 \%$ sulphate $)$ or interbeds of mudstone and halite, with large halite crystals (Fig. 13.8a). This latter Haselgebirge texture indicates that the halite was produced within the mudstones, from saline groundwater (Arthurton 1973). Tucker (1981) described giant (c. $10 \mathrm{~m}$ width) polygons within halite beds, indicative of long-term shrinkage by desiccation or de-watering. The halite is usually interbedded with blocky mudstones, but interbedding with the laminated facies is not uncommon (Arthurton 1980; Wilson 1990, 1993; Jackson et al. 1995). Laminated halite may show evidence of penecontemporaneous dissolution, erosion and collapse (Arthurton 1973; Wilson 1990, 1993). Halite-bearing mudstones are most common at or below the level of the Arden Sandstone Formation.

Gypsum (and celestite) occurs either as nodules or as more substantial beds, sometimes interbedded with mudstones (Curtis 1982). Secondary forms of either gypsum veins or dispersed gypsum crystals also occur in the other facies. It may display chicken-wire texture, or enterolithic texture (Tucker 1978), sometimes replaced by dolomite (Fig. 13.8b). These textures have been interpreted as a result of precipitation from saline groundwater, due to pedogenic or early diagenetic activity (Wright \& Sandler 1994). The cliff sections east of Blue Anchor, on the north Somerset coast (Bristol Channel) are some of the best locations to observe these textures.

\section{Environmental significance of evaporites}

The occurrence of thick halite units within basinal successions of the Mercia Mudstone Group, has prompted some to suggest a marine water source for such units, based on the large quantity of salt required to form such deposits (Wills 1970; Arthurton 1980), and the $\mathrm{Br}, \mathrm{Sr}, \mathrm{K}$ and $\mathrm{Mg}$ content of some of the halites (Thompson 1990). However, the stratigraphic separation of halite and sulphate deposits has always posed problems for this hypothesis (Wills 1970). Taylor (1983), in an isotopic study of sulphates in the Branscombe Mudstone Formation and Blue Anchor Formation of the East Midlands, concluded that some of the sulphates were sourced from continental brines and others from marine brines. An input from distant marine-sourced brines is not unusual in present-day interior rift basins, due to down-wind derivation of marine aerosols or halite dust (Clark \& Smith 1988; Rosen 1991). The presence of Mg-enriched clays has also been used by Jeans (1978) and Leslie et al. (1993) to suggest a marine-source of the Mg. Wright \& Sandler (1994) have challenged this view and implicated a model using evolution in continental groundwater that explained both sulphates and Mg-rich clays.

Marine microplankton are known from some mudstone members in the Cheshire Basin and the Midlands (Earp \& Taylor 1986; Wilson \& Evans 1990; Warrington \& IvimeyCook 1992; Barclay et al. 1997). In addition, the Tarporley Siltstone Formation possesses organic walled acritarchs and tasminid algae (Warrington 1974; Rees \& Wilson 1998), a Lingula fauna (Poole 1978) and a 'marine-like' trace fossil assemblage (Ireland et al. 1978). Hence, the evidence, other than presence of halite, would suggest the most likely interval for 'marine incursions' would be in the Anisian, rather than within the Carnian where halites are more widespread. Yet the abundant mudstone layers within Anisian (and Carnian) halites would require many seawater inundations, without leaving substantive sedimentary evidence of major floods or the seawaterderived sulphates. It seems more probable that the halite may have been aeolian-sourced along with the red desert dust (cf. Dare-Edwards 1984; Clark \& Smith 1988), perhaps from deflation of down-wind, marine-derived saline lakes in the North Sea Basin, or by monsoonal winds from the Tethys. The Southern North Sea Basin contains major marine halites starting in the Anisian. The marine microplankton may also have arrived in the dust, but found better conditions for preservation in the non-red mudstones (Glennie \& Evans 1976). The aeolian salts may also have come from uplifted and eroded Zechstein salts (Wills 1970).

\section{The sandstones}

Sandstone intervals within the Mercia Mudstone Group are most common at about the level of the Arden Sandstone Formation (Ruffell 1991; Barclay et al. 1997). These are usually white to pale grey to green, very-fine-grained, well-sorted sandstones, commonly laminated or cross-laminated, and occasionally containing mudstone rip-up clasts, erosional bases and mudcracks (Fig. 13.7d, Plate 22) (Klein 1962; Milroy 1998) The sandstones are commonly intimately interbedded with laminated to structureless grey, green and purple mudstones and siltstones. The thicker sandstones may display a wide variety of trace fossils, often of the Skolithos, Planolites or Phycodes associations (Ruffel 1991; Barclay et al. 1997; Porter pers. comm. 2005). Some intervals may display soft-sediment deformation, or the development of rootletted soils (Barclay et al. 1997; Porter pers. comm.). The sandstones within the Arden Sandstone Formation are frequently channelized deposits, which display a limited lateral extent of at best a few kilometres (Simms \& Ruffell 1990; Ruffell 1991; Barclay et al. 1997). The sandstones probably represent a variety of channel and splay deposits of a fresh-brackish water river system, representing a wetter period in the Carnian, when eastwards-directed fluvial systems at the Welsh and Cornubian massif margins disgorged into lake systems which had persistently higher levels than at other times in the Triassic (Ruffell 1991). This interlude may correlate with the Schilfsandstein in the Central European Basin, when extensive fluvial systems extended southwestwards from Fennoscandia (Beutler \& Häussaer 1981; Geluk 2005b). Thin pale grey-green sandstone and siltstone intervals (mostly less than $0.3 \mathrm{~m}$ but occasionally up to $1-3 \mathrm{~m}$ thick) are also known from the Sidmouth Mudstone and Branscombe Mudstone formations particularly in the Midlands where they are referred to as 'skerries' (Elliot 1961; Worssam \& Old 1988; Milroy 1998; see below). The lateral continuity of these is limited, indicating the locally sourced nature of these coarser particles, perhaps from riverine input into the Mercia Mudstone playas. 


\section{Triassic extensional basins}

Many of the Triassic rifts and basins in England and Wales had a common origin from the Permian (or even the Late Carboniferous; Chadwick \& Evans 1995); regional differences are examined here.

The southern North Sea and eastern England in the Triassic comprised an area of subsidence that extended from the eastern Pennines into Poland, which in the UK is bounded to the north by the Mid North Sea High and to the SW by the London Brabant High (Fig. 13.6). This basin is a broad, thick depression suggestive of thermal subsidence. However, the existence of fault topography and synfault deposition indicates that mechanical stretching (in common with the western Permian basins) was a feature of Triassic tectonics. This aspect has only recently become clear (Griffiths et al. 1995), since salt tectonics (halokinesis) from movement of the underlying Zechstein has obscured the Triassic thickness distributions, observed from borehole correlation and on seismic data. This halokinesis problem has obscured the synsedimentary faults which were particularly active in the Mid-Late Triassic (Allen et al. 1994).

As noted in Chapter 12, the Cheshire and East Irish Sea basins (Fig. 13.6) are within the tectonic- faulting province known as the Clyde Belt (Anderson et al. 1995), and originated during Permian rifting. The effects of this rifting became very pronounced throughout the Triassic, with dramatic synsedimentary thickness changes occurring across major fault systems. The Wem-Red Rock Fault system (Cheshire Basin) is an example of such a fault, with over $1000 \mathrm{~m}$ of throw in some locations preserving a similar thickness of Triassic sediment on its western (hanging wall) side.

The Vale of Eden is a NNW-SSE-trending fault-bounded basin flanked by the Alston and Askrigg blocks (Holliday et al. 2004), and shows evidence of Late Carboniferous (Variscan) strike-slip, followed by Permian-Triassic extension, a history seen in other basins. In contrast the Solway Firth and Carlisle basins (Fig. 13.6) show a very strong alignment to the underlying NE or ENE trending Lower Palaeozoic structure.

In central England, the thickest Triassic sequences are in the N-S-trending Worcester Basin. Here, Precambrian and Lower Palaeozoic rocks were juxtaposed with $1.5 \mathrm{~km}$ of Triassic redbeds by the East Malvern Fault (Fig. 13.6). The basin is also fault-bounded to the east, juxtaposing the Triassic succession against concealed Palaeozoic rocks of the London-Brabant Massif (Sumbler et al. 2000).

In the Wessex Basin (Fig. 13.6), the thickest Triassic succession is preserved in the western part, thinning towards the east and the south beneath the Isle of Wight and towards the French side of the English Channel (Butler 1998). The basins of the Western Approaches, Bristol Channel, Celtic Sea and Cardigan Bay have a complex history of subsidence and inversion that has resulted in variable preservation of the Triassic, except within the deeper offshore depocentres such as the Plymouth Bay and Melville basins of SW England. In the Plymouth Bay Basin a Permian and Triassic red bed succession of over $9 \mathrm{~km}$ in thickness occurs, making this the deepest 'red-bed' basin of the postDevonian in NW Europe (Harvey et al. 1994; Tappin et al. 1994). Extensional faults that were active during Triassic deposition in basins offshore of SW England and South Wales were often inherited from underlying ESE-oriented Variscan thrusts and extensional faults. During the Lower Triassic these produced presumably subdued foreland basins receiving sediment from the surrounding Variscan mountains. It is probably not until the deposition of the Mercia Mudstone Group that some of these southern basins were linked.

\section{Eastern England and the Southern North Sea Basin}

The eastern England Triassic succession is contiguous with that of the Southern North Sea Basin. Onshore the thickest Triassic is present in Yorkshire and Lincolnshire, and offshore in the Sole Pit Trough, where up to $1.6 \mathrm{~km}$ occurs. As a result of North Sea hydrocarbon exploration the regional variations in the Triassic succession are well understood, although there is a separate lithostratigraphy for onshore and offshore areas (Figs $13.3 \&$ 13.4). The offshore Triassic below the Hunconformity forms the Bacton Group, and that above the Haisborough Group (Cameron et al. 1992). Much of the information for both offshore and onshore successions is derived from borehole records because of the extensive cover of later sediments (Warrington 1974; Warrington et al. 1980). The bestdescribed outcrop successions occur on the Triassic basin margin in Nottinghamshire (Benton et al. 2002).

The base of the Triassic in the southern North Sea can be located accurately within cycle 5 of the Lower Buntsandstein a short distance $(c .30 \mathrm{~m})$ above the log-marker represented by the Bröckelscheifer (Geluk 2005b). The Bröckelscheifer is a siltstone unit whose equivalent in the German succession is assigned to the uppermost Zechstein (Szurlies et al. 2003). The silty nature of this unit can be recognized on borehole logs in the lower part of the Roxby Formation in NE England (Fig. 13.3) (Berridge \& Pattison 1994). Hence, the base of the Triassic equates to a horizon within the upper part of the Roxby Formation (Eskdale Group) of NE England, and within the lower part of the Bunter Shale Formation (part of the Bacton Group) in the UK offshore succession (Fig. 13.9). Both the Roxby Formation and the Bunter Shale Formation are dominated by red-redbrown silty mudstones, with rare dolomite and anhydrite-rich layers.

Southwards and westwards from the coastal regions of NE England the Roxby Formation progressively interdigitates with the Sherwood Sandstone Group, so that by the Retford area, the Roxby Formation is absent. Southwest of this area the Sherwood Sandstone oversteps older units of the Upper Permian (Warrington et al. 1980; Berridge et al. 1999). Hence towards the SW parts of the East Midlands Shelf the PermianTriassic boundary is either within the lower part of the Sherwood Sandstone Group, or represented by a disconformity at the base.

\section{Sherwood Sandstone and Bacton Groups}

In Nottinghamshire the Sherwood Sandstone Group is represented by the Lenton Sandstone Formation (which is in part Permian) and the overlying Nottingham Castle Sandstone Formation (Fig. 13.3). The Lenton Sandstone is predominantly a cross-stratified reddish-brown, fine- to medium-grained sandstone, with layers of mud-cracked mudstone and siltstone. The sandstones are dominantly aeolian in origin (Howard per comm. 2005) although the formation contains intervals of stacked fluvial fining-up successions, with basal lags of mudstone clasts, and rare quartzite clasts (Warrington 1974). It may also include thin intervals of breccia, and rare ventifact layers.

The Nottingham Castle Sandstone Formation is a mediumcoarse pebbly sandstone with beds of conglomerate; pebbles are well-rounded and consist of quartzite and limestone (Warrington 1974). The sandstones are arranged in 2-4 m-thick cross-stratified sets, with bounding and foreset surfaces commonly containing pebbles and mudstone clasts. Rare palaeosols and ventifacts have been reported (Taylor 1968; Benton et al. 2002). The distribution and palaeocurrent measurements of the Nottingham Castle Sandstone Formation shows it formed a NE- to E-directed wide braided alluvial fan, which extended into Humberside and to the Lincolnshire coast (Fig. 13.5a) (Warrington 1974). North of Doncaster and beyond the fan it passes laterally into the onshore undivided Sherwood Sandstone Group, and to the east it passes offshore into the Bunter Sandstone Formation (Fig. 13.3) (Warrington \& Ivimey-Cook 1992). This is achieved by a progressive reduction in pebble size, and abundance, and an increase in the proportion of finergrained sandstones and mudstone-rich intervals (Warrington 1974; Warrington et al. 1980). 


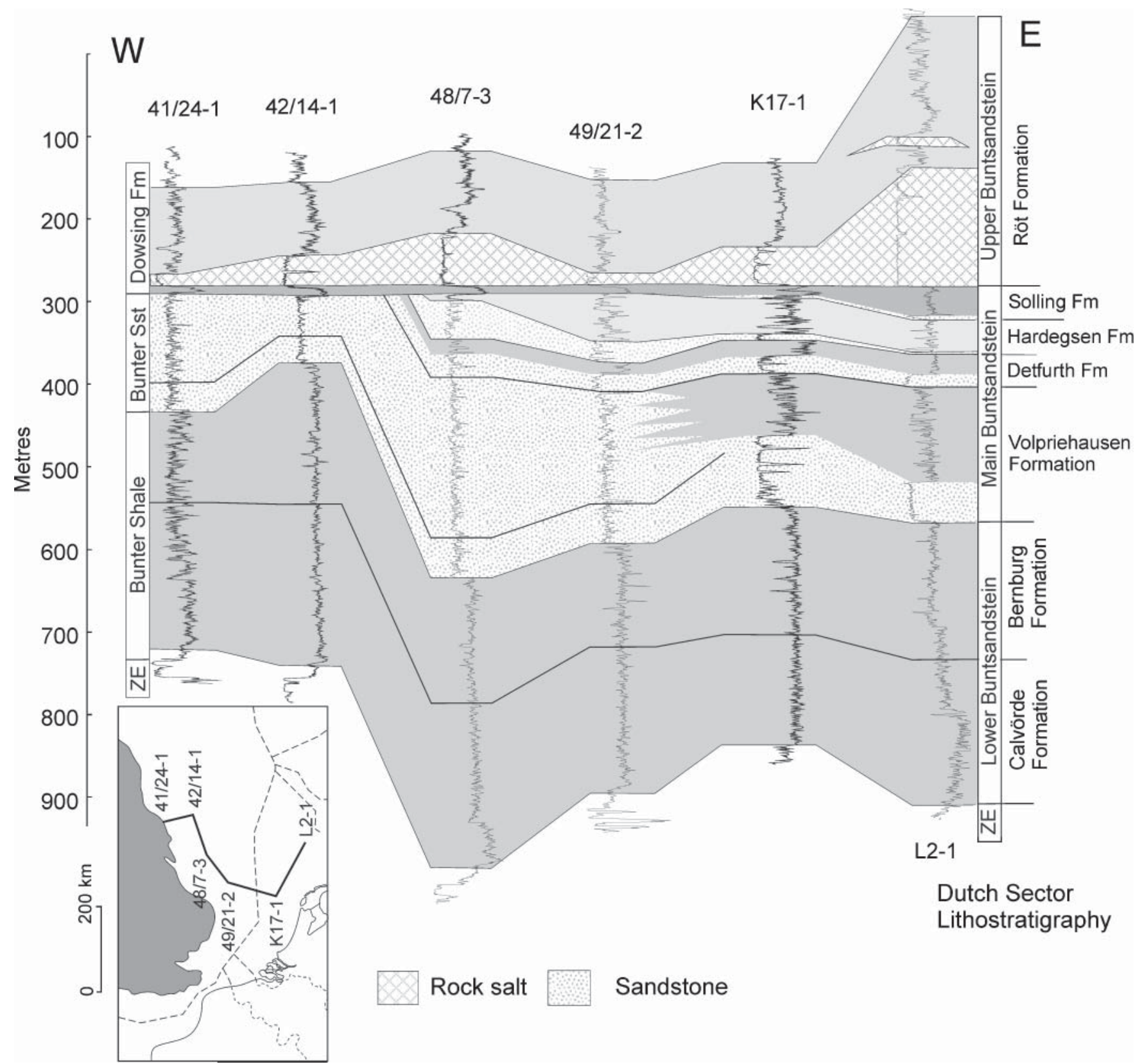

Fig. 13.9. Log correlation of the Lower Triassic succession from the English part of the Southern North Sea into the Dutch sector, showing the transition from the Bunter Sandstone Formation in the English sector into the classic Buntsandstein log-stratigraphy in the Dutch sector (modified from Geluk 2005a). Mudstone units in various shades of grey. ZE, Zechstein.

Palaeocurrent measurements from the Sherwood Sandstone Group throughout onshore eastern England indicate that fluvial transport systems were directed in a broad swath to the NE-SE (Taylor 1968; Warrington 1974; Gaunt 1994; Benton et al. 2002). This suggests much of this sand was derived from the region of the Pennine high to the west as well as from the distal Budleighensis river system draining into the East Midlands Shelf from the West Midlands. The rarity of pebbles in the Pennine-derived Sherwood Sandstone Group north of Doncaster probably attests either to the low relief of the Pennine High or the limited catchment of the river systems supplying sediment eastwards.

The Bunter Shale Formation of the southern North Sea is between 200 and $500 \mathrm{~m}$ thick with dramatic thickness changes indicative of synsedimentary activity, commonly obscured in basinal areas by extensive salt movement from the underlying Permian and overlying later Triassic successions. The offshore
Bunter Shale Formation is the equivalent of the upper part of the onshore Roxby Formation and the lower part of the Sherwood Sandstone Group (Fig. 13.3). The younger part of this interdigitation is represented by the Amethyst Member, a succession of interbedded fluvial channel and sheet-flood sandstones and lacustrine mudstones (Fisher \& Mudge 1998). The Amethyst Member is up to $340 \mathrm{~m}$ thick immediately offshore from Lincolnshire, and is laterally equivalent to the Rogenstein Member of the Bacton Group (Cameron et al. 1992), in turn the lateral equivalent of the Bernburg Formation of the German Basin, which is Dienerian (late Induan) in age (Fig. 13.9) (Szurlies 2004).

The Bunter Sandstone Formation is a predominantly finegrained, or occasionally medium-grained, cross-stratified sandstone with common mudstone interbeds. Close to the English coast it is a general coarsening-up unit, but lacks recognisable units on wire-line logs that could be used for subdivision 
(Fig. 13.9). However, at its eastern and NE borders with the Dutch sectors of the southern North Sea, it shows three major fining-up cycles, which can be linked to the Germanic and Dutch basin lithostratigraphy using wireline logs (Fisher \& Mudge 1998; Geluk \& Röhling 1999; Michelsen \& Clausen 2002; Geluk 2005b). These three cycles represent the Volpriehausen, Detfurth and Hardegsen formations of the German and Dutch basins (Fig. 13.9) (Geluk \& Röhling 1999; Szurlies et al. 2003; Szurlies 2004). Each of these cycles is a northwardsprograding alluvial-fan or braided river complex, separated by flood-plain or lacustrine mudstones, sourced from the basement highs to the south (Fisher \& Mudge 1998). Tectonism seems to have been important in producing these cycles, for each is initiated with an erosional unconformity, preceded by slight regional folding (Geluk \& Röhling 1999; Geluk 2005b).

\section{Mercia Mudstone GrouplHaisborough Group}

The events responsible for the H-unconformity in the southern North Sea must have produced considerable relief, for the predominantly fine-grained unit that followed it, the Dowsing Formation (Upper Buntsandstein, in Dutch sector) locally cuts down through substantial parts of the Lower Triassic succession throughout the southern North Sea (Fig. 13.9) (Geluk \& Röhling 1999; Geluk 2005b). Onshore the extent of this erosion is uncertain, but in parts of the Midlands, for example, it seems probable that an equivalent of the Wildmoor Sandstone Formation may have been entirely removed, due to erosion down into the pebble-bearing beds lower in the Sherwood Sandstone
Group. In the NE part of the UK sector of the southern North Sea, the base of the Haisborough Group is diachronous, for a sandstone equivalent to the Solling Formation of the Dutch and German basins is present at the base (Cameron et al. 1992; Geluk \& Röhling 1999). Westwards this passes into the Tarporley Siltstone Formation of the Nottingham area, which is in part the time equivalent of the Bromsgrove Sandstone Formation of the West Midlands (Figs 13.4 \& 13.10).

A period of erosion at the base of the Mercia Mudstone Group is indicated in the Nottingham area by dreikanterbearing gravels at the junction with the underlying sandstones (Swinnerton 1918; Warrington 1974). In the southern North Sea the Haisborough Group approaches $1000 \mathrm{~m}$ in maximum thickness in the Sole Pit Trough area of the southern North Sea, and is dominated by red silty mudstones (Fig. 13.11). The offshore Dowsing and Dudgeon formations are punctuated by four halite units, between which the succession is divided into a large number of mudstone and dolomitic units. The lowest halite, the Main Röt Halite Member, is the most widespread of the halites, extending into NE England as the Esk Evaporite Member (Fig. 13.4). This unit is composed of five cycles of marine flooding and evaporation, with contemporary anhydritic and dolomitic mudstone sabkha-facies on basin margins (Figs 13.5b \& 13.11). The overlying Upper Röt Halite does not extend into onshore England, being restricted to the northern half of the Anglo-Dutch Basin (Figs. 13.6 \& 13.11). The Muschelkalk Halite Member is divided by numerous thin red mudstone beds which become less common upwards through the member, and as with lower units the halite laterally
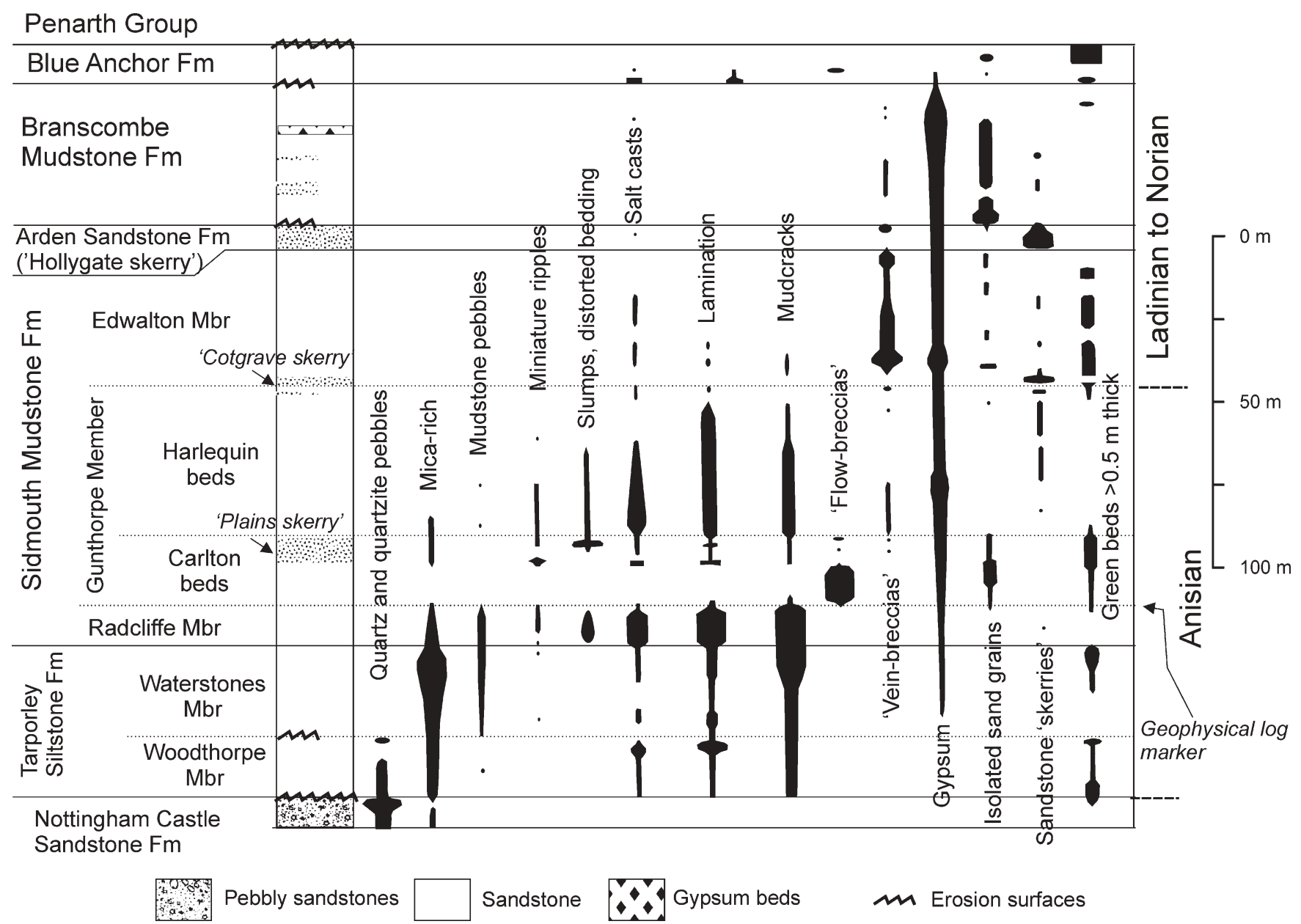

Fig. 13.10. Detail of the sedimentological structures in the Mercia Mudstone Group in borehole cores from the Nottingham area. Modified from Elliot (1961), using the lithostratigraphy of Howard et al. (2006). 


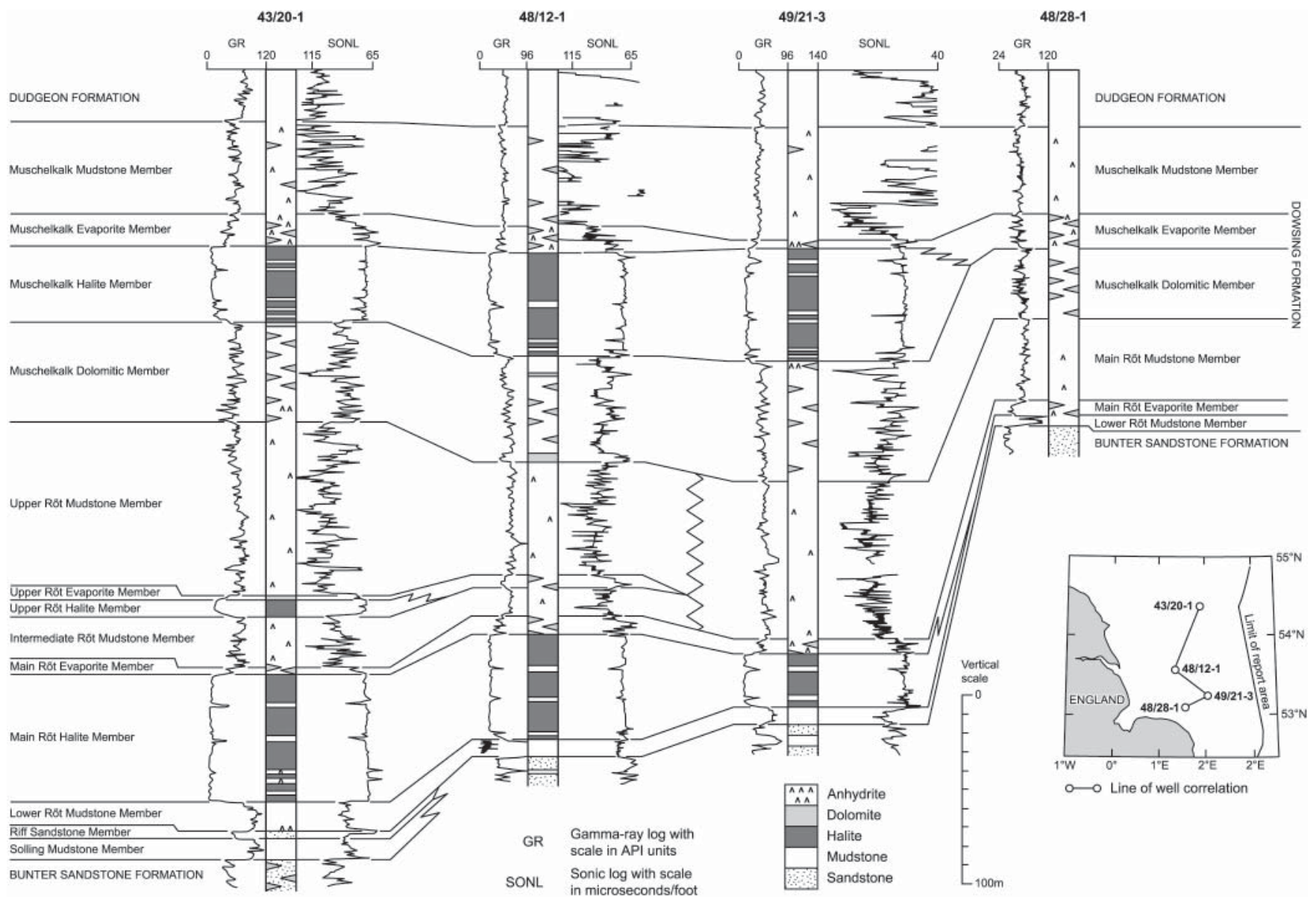

Fig. 13.11. Wireline log correlation of the Dowsing Formation, and its associated sub-divisions in the southern North Sea (modified from Cameron et al. 1992).

interfingers with sabkha dolomitic and anhydritic mudstones towards the basin flanks. The Keuper Halite Member (up to $300 \mathrm{~m}$ thick) is largely restricted to the Sole Pit Trough in the UK southern North Sea (Fig. 13.5c). Owing to large thickness changes, and lateral impersistance of the halite beds, the Keuper Halite appears to have been deposited in a large number of small shallow saline lakes (reflecting the palaeotopography), rather than laterally extensive salinas like in the older halites of the Dowsing Formation (Fisher \& Mudge 1998). The Keuper Halite also appears to have been fed by riverine flow or ground waters, since lateral marine connection to the east was disrupted during the Carnian (Zeigler 1990; Geluk 2005a).

The thickness and depositional limits of units of the Haisborough Group are strongly affected by the Dowsing Fault Zone, which delimits the western boundary of the Sole Pit Trough, indicating that contemporaneous fault movements dictated deposition rates. The Triton Formation is dominated by red anhydrite-bearing mudstones, with anhydrite layers numerous enough in the middle parts of the formation to define the Keuper Anhydrite Member, which has a wide distribution throughout the offshore region. In onshore regions in eastern England the Keuper Anhydrite is probably represented in Nottinghamshire, Leicestershire and Staffordshire by the Tutbury and Newark Gypsum, that occurs in the upper $40 \mathrm{~m}$ of the Branscombe Mudstone Formation (Fig. 13.4) (Taylor 1968).

The lithostratigraphy of the Mercia Mudstone Group in onshore eastern England has largely evolved around that first erected by Elliot (1961). He divided the succession below the Arden Sandstone Formation (his Hollygate skerry) into four units, two of which are dominated by laminated mudstones (now the Radcliffe Member and Harlequin beds; Berridge et al. 1999; Howard et al. 2006) and two that are dominated by nonlaminated mudstones (Carlton beds and Edwalton Member; Fig. 13.10). He also proposed units for the mudstones (now Branscombe Mudstone Formation) above the Hollygate skerry and two units which are now assigned to the Tarporley Siltstone Formation (Fig. 13.10). The vein breccias of Elliot (1961) are common in the Edwalton Member (Fig. 13.10). Elliot's 'flowbreccias' are in beds up to $4 \mathrm{~m}$ thick, interbedded with less disturbed mudstone beds, and are common in the lower part of the Carlton beds. From Nottingham westwards, Elliot's laminated and non-laminated mudstone divisions can be traced perhaps as far west as the Coventry area (Old et al. 1987), and north as far as the Grimsby area (Berridge \& Pattison 1994).

The boundary between the Gunthorpe and Radcliffe members provides a gamma-ray peak in wire-line logs, which has provided an alternative means to correlate this lithostratigraphy into other onshore areas in eastern England (Berridge \& Pattison 1994). Traced northwards this regional gamma marker appears to equate with an interval above the Esk Evaporite Member (Howard pers comm.). This later correlation is compatible with dating of these successions by miospores which indicates the succession near the base of the Edwalton Formation probably corresponds to the Anisian-Ladinian boundary (Worssam \& Old 1988).

\section{Economic Geology}

Triassic hydrocarbon reservoirs in the southern North Sea are minor in comparison to the large number of Permian (Rotliegende) gas reservoirs (Fig. 13.12), these all being based on Late Carboniferous sourced gas migrating into the Permian 


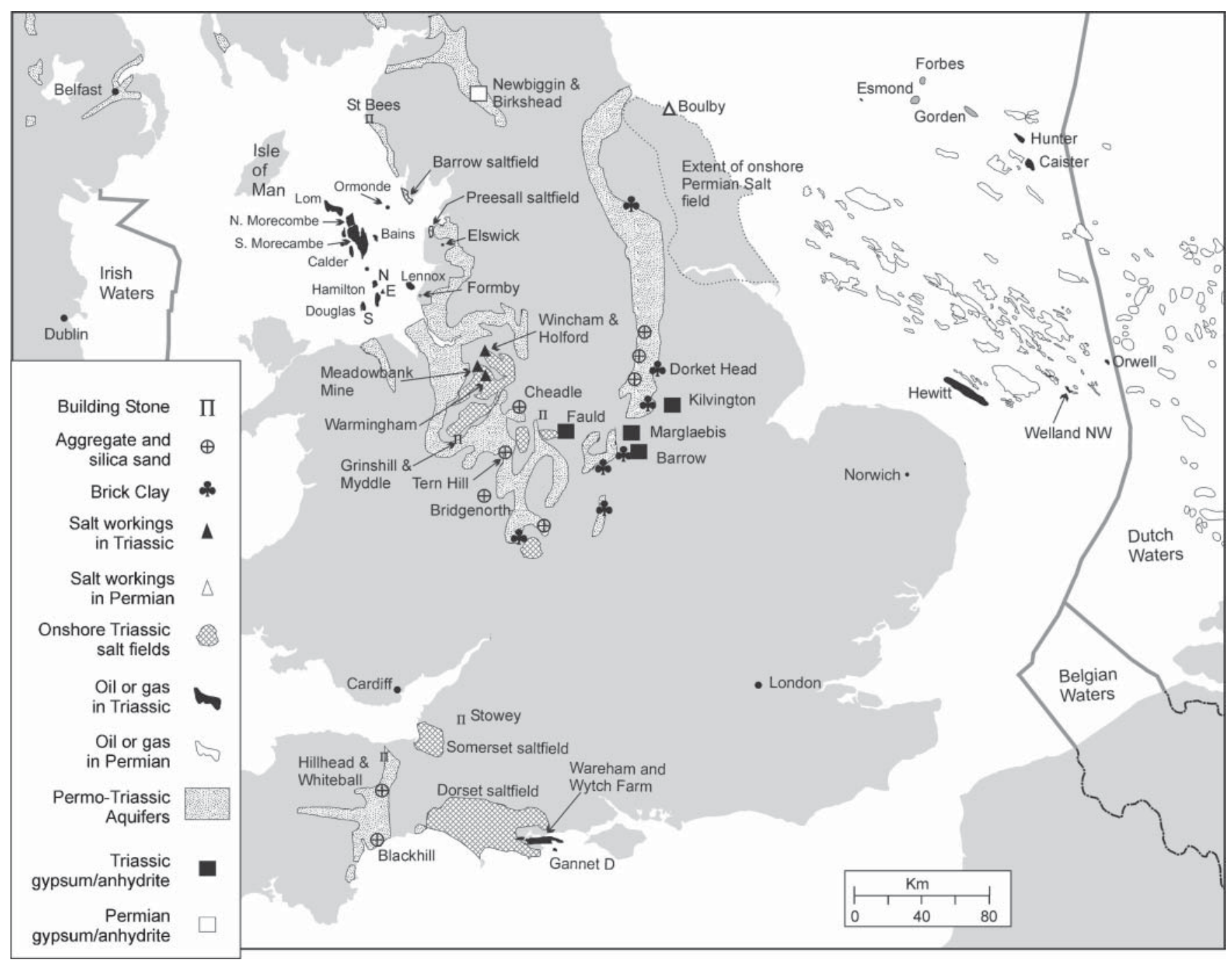

Fig. 13.12. Location of main worked economic resources in the Triassic, with some Permian resources also indicated. Building stone, aggregates, silica sand and brick clay only indicated for the Triassic. Triassic oil and gas fields decommissioned in grey.

and Triassic reservoirs (Fisher \& Mudge 1998). The Triassic Bunter Sandstone gas reservoirs are relatively poor quality fluvial sandstones, with overlying mudstones of the Haisborough Group as the topseal (Ritchie \& Pratsides 1993). The earliest of these discoveries was the Hewitt field (latest Permian in this account) in 1966, followed by the Caister, Gorden and Forbes fields in the late 1960s-early 1970s (Bifani 1986), with the last Triassic discovery being the Hunter gas field in 1992.

Just as the Bunter Sandstone reservoir and Haisborough Group mudstones form an effective topseal for the hydrocarbon play in the southern North Sea, the same two units, onshore and at shallower depths, form aquifer and aquiclude for water abstraction. In the UK as a whole, groundwater resources in Permo-Triassic sandstone aquifers are the second most important after the Chalk, providing some $25 \%$ of the total licensed abstractions. This resource in northern and central England, around the flanks of the Pennines, is particularly important in providing water supplies for industrial and potable uses in cities such as Manchester, Liverpool, Nottingham and Birmingham, located over the aquifer.

In Nottinghamshire the Sherwood Sandstone aquifer (which includes the Lenton Sandstone) is a heavily used supply of potable water (Trowsdale \& Lerner 2003); further NE in Yorkshire, the finer-grained nature of the Sherwood Sandstone along with the lower water quality (higher salinities, harder water) limit abstractions to industrial uses. Generally, fractures in the
Sherwood Sandstone contribute significantly to transmissivity, lesser so in the south around Nottingham where intergranular flow is important (Allen et al. 1997).

In Nottinghamshire poorly consolidated parts of the Sherwood Sandstone Group are an important source of sand and gravel accounting for some $30 \%$ of the county's output. Most of the quarries are located between Nottingham and Mansfield and mostly utilize the Nottingham Castle Sandstone Formation. A single site (Ratcher Hill quarry) also produces specialist (non-aggregate) silica sand (high silica content sand) for a variety of purposes (Highley et al. 2004c). In the past, both Scrooby Top and Styrrup quarries in Nottinghamshire were important sources of red loose sand and some sandstone; both now have preserved faces under the Geological Conservation Review of sites of special scientific importance.

Onshore the Branscombe Mudstone Formation of the Mercia Mudstone Group locally hosts beds of gypsum$\mathrm{CaSO}_{4} \cdot \mathrm{H}_{2} \mathrm{O}$ (anhydrite- $\mathrm{CaSO}_{4}$ below $40-50 \mathrm{~m}$ ), which are used commercially for the production of plaster, plasterboard and cement (Highley et al. 2004a). The most important resources are those associated with the Tutbury Gypsum in Leicestershire, Nottinghamshire (and Staffordshire) and the Newark Gypsum in east Nottinghamshire. The Tutbury Gypsum is a bed up to $3.5 \mathrm{~m}$ thick and is worked underground using the pillar and stall method at the Barrow Mine in Leicestershire and the Marglaebis Mine in Nottinghamshire (also the Fauld 
Mine in Staffordshire; Fig. 13.12). The Newark Gypsum in Nottinghamshire comprises multiple beds and nodular bands of gypsum of variable thickness and purity, spread over some 15$18 \mathrm{~m}$ of the Branscombe Mudstone Formation, and is worked at the Kilvington open cast quarry. The individual worked beds range from about 0.3 to $2 \mathrm{~m}$ in thickness with some of the beds producing the highest quality UK gypsum (Highley et al. $2004 a$ ). The amount of gypsum extracted has declined appreciably over the last 25 years due to importation of cheaper gypsum and availability of gypsum as a by-product from flue gas desulphurization of coal-fired power stations.

One of the last remaining brick clay producing sites from the Mercia Mudstone Group in eastern England is the Dorket Head quarry, to the north of Nottingham, which works the lower part of the Sidmouth Mudstone Formation, producing facing bricks.

\section{Northwest England, North Wales and the East Irish Sea Basin}

The basins and sub-basins in NW England and the East Irish Sea contain some of the thickest proven Triassic successions in onshore or offshore UK basins, with up to $2 \mathrm{~km}$ of Sherwood Sandstone Group and $3.2 \mathrm{~km}$ of Mercia Mudstone Group sediments (Jackson et al. 1995). Much of this succession is very poorly exposed, other than fragments of the Sherwood Sandstone Group within the Cheshire Basin and on the Lancashire and west Cumbria coasts, so the succession is largely known from boreholes. The Penarth Group and upper parts of the Mercia Mudstone Group were probably deposited across the current Lower and Middle Triassic outcrop, but are now only known from isolated outliers in the Cheshire Basin, the Carlisle Basin and offshore in the Solway-Firth and Keys basins (Jackson et al. 1995; Warrington et al. 1999).

There is no fossil evidence to firmly place the position of the Permian-Triassic boundary in the successions in NW England. However, based on wireline-log similarities to the southern North Sea, the base of the Triassic is probably within the St Bees Shale, but it is commonly placed for convenience at the base of the St Bees Sandstone Formation (Jackson et al. 1987), even though this boundary is diachronous (Holliday et al. 2001). Within the onshore basins, the aeolian sandstones of the Kinnerton Sandstone Formation (partly Permian in age) rest conformably upon the Permian Manchester Marl and Bold Formation in the Cheshire Basin and west Lancashire (Fig. 13.3; Plate 23). The Sherwood Sandstone Group in NW England below the H-unconformity (Fig. 13.3) has failed to provide any biostratigraphic evidence of age, although magnetostratigraphy indicates its Early Triassic credentials (Mange et al. 1999; Hounslow \& McIntosh 2003).

\section{Sherwood Sandstone Group in sequence TR1}

Within the Cheshire and East Irish Sea basins (EISB) Jackson et al. (1987, 1995) divided the succession into two units, above and below a seismic reflector termed the 'brown reflector', which appears to be related to the top of a widespread interval of silicified sandstone (Colter \& Barr 1975). The lower unit, below the brown reflector, is the St Bees Sandstone Formation (Barnes et al. 1994), which is composed of stacked fluvial sandstones formed in low sinuosity braided rivers (Plate 24; Jones \& Ambrose 1994). The sandstones are commonly distinctively micaceous and are rather similar to those farther north in the Carlisle Basin (Brookfield 2004; Holliday et al. 2004). On the Cumbrian coast, within the St Bees Sandstone, detritus derived from the Lake District High diminishes in importance upwards; this parallels a change from sheetflood sandstones in the lower parts to more common stacked channel sandstones in the upper parts (Jones \& Ambrose 1994) (Plate 24).
In the EISB the unit above the brown reflector is the Calder Sandstone Formation (Barnes et al. 1994; Akhurst et al. 1997) and within the northern part of the Cheshire Basin this correlates with an interval within the Wilmslow Sandstone Formation (Fig. 13.3; Evans et al. 1993). Within the EISB the base of the Calder Sandstone appears to be a regional disconformity marked by an upwards decrease in gamma-ray values and sharp increase in sonic velocity (Barnes et al. 1994). In the southern parts of the Cheshire Basin, the brown reflector may correspond with the top of the Chester Pebble Beds Formation (Jackson et al. 1987). An overlying 'yellow' seismic reflector in the Calder Sandstone Formation of the EISB marks the top of a widespread well-cemented fluvial sandstone within the formation (Fig. 13.3) (Akhurst et al. 1997).

The Chester Pebble Beds Formation, some $90-305 \mathrm{~m}$ in thickness (Fig. 13.3), is dominated by red-brown, crossstratified, pebbly, medium- to coarse-grained sandstones with conglomerate layers, and may locally rest on Carboniferous rocks at the margin of the Cheshire Basin (Plate 23). Steel \& Thompson (1983) and Rees \& Wilson (1998) interpreted the deposits of the formation as migrating sand and gravel bars within a braided river system. Relatively uncommon parallel laminated sandstone and mudstone attest to periods of low river discharge, or to deposition in abandoned channels. Rare interbedded aeolian cross-stratified sandstones (Rees \& Wilson 1998) and the presence of aeolian-rounded sand grains indicate some reworking of the fluvial deposits by wind winnowing.

The Wilmslow Sandstone Formation comprises red, nonpebbly cross-stratified fine- to medium-grained sandstone. Rees \& Wilson (1998) and Thompson $(1970 a, b)$ recognized a fluvial facies, composed of poorly sorted sandstone with mud clasts, and a well-sorted, paler-coloured aeolian sandstone facies. The fluvial sandstones dominate the interval below the brown reflector, whereas the aeolian sandstones are more prevalent above this and at the margin of the Cheshire Basin (Steel \& Thompson 1983). The Wilmslow Sandstone Formation varies greatly in thickness from $900 \mathrm{~m}$ in the centre of the Cheshire Basin to absent at some basin margin locations. This appears to be due to both truncation below the Helsby Sandstone Formation and primary depositional thinning (Evans et al. 1993; Rees \& Wilson 1998).

In the northern parts of the Cheshire Basin and southern part of the EISB there is a lateral transition from the Chester Pebble Beds and Wilmslow Sandstone of the Cheshire Basin into the $\mathrm{St}$ Bees Sandstone Formation of the EISB. This is indicated by the progressive northwards loss of quartzite pebbles within the $\mathrm{St}$ Bees Sandstone Formation in the southern parts of the EISB (Jackson et al. 1995). In the southern parts of the EISB heavy mineral data show the sediment source of the St Bees Sandstone to be the Welsh Massif. Evidently, the Armorican sourced detritus in the Midlands and Cheshire Basins was considerably diluted by material derived from local highs by the time it reached the central EISB.

To the west of the Cheshire Basin, in the Vale of Clwyd, Permo-Triassic sandstones of uncertain age, mainly of aeolian origin, occur beneath thick drift deposits. These may be equivalent in age to the Kinnerton Sandstone Formation of the Cheshire Basin, since they contain no known pebble-bearing beds equivalent with the Chester Pebble Beds (Warrington et al. 1980).

Near the Cumbrian coast the Calder Sandstone Formation is dominated by aeolian dune sandstones and various wet interdune facies, whereas within the western and central EISB, it contains much larger proportions of fluvial sandstones, which were deposited in channel systems directing flow to the WSW. This unit is also recognized to the north in the western parts of the Carlisle Basin, and appears to be the equivalent of part of the aeolian Kirklington Sandstone Formation of northern Cumbria (Holliday et al. 2004). The upland areas to the east of the EISB seem to have been a major source for the wind-derived 
grains in the Calder Sandstone that were transported by northeasterly winds (Jones \& Ambrose 1994).

The transition from the Calder Sandstone Formation into the Ormskirk Sandstone Formation of the EISB is not marked by a major unconformity (Akhurst et al. 1997), whereas the equivalent boundary in the Cheshire Basin, shows removal of up to about $900 \mathrm{~m}$ of strata. In the EISB the Calder SandstoneOrmskirk Sandstone boundary is a sharp disconformable boundary, indicated on wire-line logs by an upwards increase in sonic velocity and gamma-ray values, which are concomitant with a major environmental change, and a shift in the palaeocurrent directions. In the Cheshire Basin the Bulkeley Hill Formation locally underlies the H-unconformity (Warrington et al. 1980), may be up to $220 \mathrm{~m}$ thick (Evans et al. 1993) and is equivalent, in an uncertain way, to the upper part of the Calder Sandstone Formation.

\section{Sherwood Sandstone Group in sequence TR2-3}

In the Cheshire Basin the topmost unit of the Sherwood Sandstone Group, the Helsby Sandstone Formation (up to c. $250 \mathrm{~m}$ thick), contains Anisian tetrapods and palynomorphs, as well as crustaceans and ichnofossils (Benton \& Spenser 1995; Warrington et al. 1999; King \& Thompson 2000). In the centre and NW of the Cheshire Basin the sandstone units adjacent to the $\mathrm{H}$-unconformity are divided into three members, a lower aeolian and fluvial unit (the Thurstaston Sandstone Member), a middle fluvial pebbly sandstone unit (the Delamere Member) and an upper aeolian sandstone (the Frodsham Member; Thompson 1970b; Warrington et al. 1980). The lowest member has been assigned by the British Geological Survey to the Wilmslow Sandstone Formation and the higher two members to the Helsby Sandstone Formation. The precise placement of the $\mathrm{H}$-unconformity seen on seismic reflection profiles in the Cheshire Basin is uncertain. Thompson (1970b) and Mountney \& Thompson (2002) place it as the base of the Thurstaston Sandstone Member, whereas the Geological Survey (Poole \& Whiteman 1966; Evans et al. 1993) placed it more naturally at the erosive base of the fluvial pebbly sandstones of the Delamere Member (base of Helsby Sandstone Formation). The aeolian sandstones of these units were formed by large domeshaped dunes that migrated from east to west (Brookfield 1977). The interbedded fluvial sandstone units were formed by NW-migrating sandbars in a sinuous river system (Thompson $1970 a, b)$. The Helsby Sandstone Formation away from the north and NW of the Cheshire Basin is dominated by pebbly fluvial sandstones, of which the quartzite pebbles form a distinctive part and were probably in part derived from reworking of underlying parts of the Sherwood Sandstone (Rees \& Wilson 1998).

The Ormskirk Sandstone Formation of the EISB, west Lancashire and Cumbrian coasts has been extensively investigated by boreholes for it forms the major reservoir of the Morecambe Bay gas fields (Cowan 1993; Meadows \& Beach 1993; Stuart 1993). It is distinguished from the underlying Calder Sandstone Formation by being generally finer-grained and better sorted, and containing common frosted 1-2 mm diameter quartz grains (Akhurst et al. 1997). It is mostly a fineto medium-grained pale grey or brown sandstone, with thin $(<1 \mathrm{~m})$ interbeds of green or red-brown mudstone. Within the central EISB the sandstone units appear to be dominated by fluvial channel deposits, produced by SW- to west-flowing river systems (Cowan 1993; Meadows \& Beach 1993; Stuart 1993). This is in marked contrast to the Cumbrian coast, Isle of Man and the Carlisle Basin, where the unit is dominated by aeolian sandstones, produced by SW migrating dunes (Jones \& Ambrose 1994; Jackson et al. 1995; Brookfield 2004). This difference may in part be due to localized control of the distributary fluvial channels by synsedimentary fault networks (Meadows \& Beach 1993), or perhaps due to uncertainty in the correct environmental interpretation of 'sheetflood' type sandstone intervals common in this formation (Goodall et al. 2000).

\section{Mercia Mudstone Group}

It is probable that the Mercia Mudstone Group was originally deposited across the entire subcrop and outcrop region of the Triassic, with the thickest deposits in the East Irish Sea, Solway Firth and Cheshire basins (Jackson et al. 1995; Holliday et al. 2004). The Mercia Mudstone Group is dominated by red mudstones, but can include substantial thicknesses of halite, and in most areas intervals of non-red mudstones.

The boundary between the sandstones of the Sherwood Sandstone Group and the red mudstones of the Mercia Mudstone Group is at the base of the Tarporley Siltstone Formation (Howard et al. 2006), although it is a transitional lithological boundary that is diachronous. The Tarporley Siltstone Formation comprises reddish-brown mudstones and siltstones with interbedded paler, fine-very fine sandstones, characteristically with a high content of mica on bedding surfaces (Fig. 13.14) (Ireland et al. 1978). Intraformational conglomerates are common along with wave and current-ripple laminated sandstones and dessication cracks and a rich variety of ichnofossils. The unit is at most $150 \mathrm{~m}$ thick within the Cheshire Basin, but is not regionally differentiated within the EISB (Jackson et al. 1995; Howard et al. 2006). In west Lancashire and Merseyside the Tarporley Siltstone Formation passes into laminated mudstones (Wilson \& Evans 1990); further north and west in the EISB it passes into dolomite and anhydrite-rich mudstones (Jackson et al. 1995). The laminated mudstones of the Lancashire coast comprise interbedded and flaser-laminated grey mudstones and siltstones, with halite psuedomorphs, along with mudcracks, current ripples and |clay-flake conglomerates (Figs 13.13 \& 13.15) (Wilson \& Evans 1990).

The successions in NW England are among the few places in the UK where the Anisian-Ladinian boundary can be defined using biostratigraphy. Within the Cheshire Basin, palynological evidence suggests this stage boundary occurs at the top of the Byley Mudstones Member or in the bottom part of the Wych Mudstones Member (Warrington et al. 1999). Farther north on the Lancashire coast, the Anisian-Ladinian boundary is located within the Coat Walls Mudstone Member, which overlies the Preesall Halite (Fig. 13.4). The overlying Wilkesley Halite may be late Ladinian, or entirely Carnian in age.

The succession below the Wilkesley Halite includes a widespread halite marker interval the Northwich Halite of the Cheshire Basin and the equivalent Preesall Halite of the EISB and west Lancashire coast (Fig. 13.4) (Wilson 1990, 1993; Jackson et al. 1995). These halites contain approximately $25 \%$ interbedded red mudstones, which progressively thicken, with the loss of the interbedded halite, towards basin margin locations. Within several hundred metres of the surface the halites may be replaced by solution collapse breccias due to post-Triassic ingress of water (Wilson 1993).

Below the Preesall Halite in the EISB and west Lancashire coast is a succession of interbedded halites and mudstones. The halite units comprise upwards of $50 \%$ halite, whereas the mudstone units comprise lesser amounts. Within the deeper parts of these basins up to three halite units, the Mythop Halite, Rossall Halite-Lower and Rossall Halite-Upper, can be recognized using wireline logs (Wilson 1990; Jackson et al. 1995). Sedimentological details about these units are known from cored boreholes in west Lancashire and SW Cumbria (Wilson 1990). Like the Preesall Halite, the halite units thin towards basin margins, with some of this loss due to penecontemporaneous dissolution of the halite, evident from collapse breccias (Wilson 1990; Wilson \& Evans 1990). The halite units below the Preesall Halite are dominantly in the Haselgebirge lithology. These halite units extend offshore to the Isle of Man, SW Scotland and Northern Ireland, and are locally mined in 


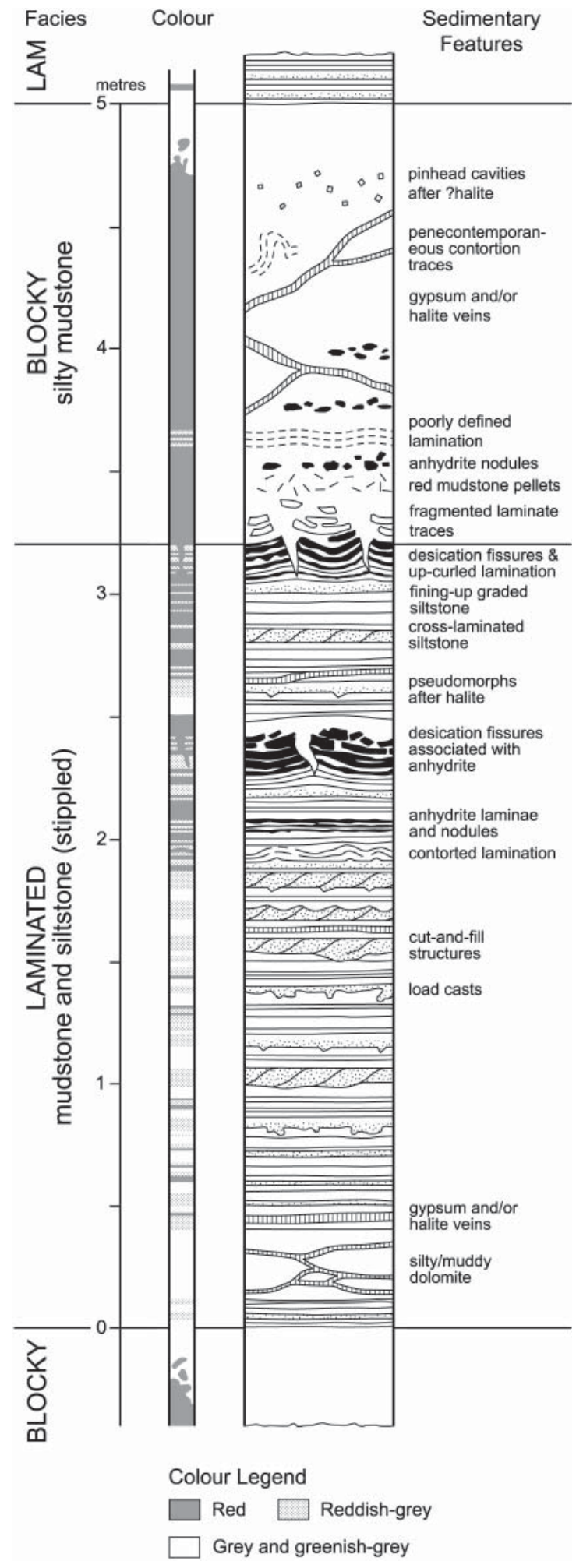

Fig. 13.13. Idealized representation of a sedimentary cycle between laminated mudstones facies and blocky mudstone facies, based on borehole records from the mudstones in the vicinity of the Northwich Halite (from Arthurton 1980).

Northern Ireland (at Kilroot), suggesting these deposits were once widespread.

Most of the intervening mudstone units are massive red mudstones, with subordinate interbeds of laminated siltstones. Exceptions are the mudstone units that overlie and underlie the Preesall Halite in west Lancashire and the Northwich Halite in Cheshire (Fig. 13.4) (Wilson 1990, 1993). These show vivid interbedding of reddish-brown and greenish grey mudstones interlaminated with thin ( $<1 \mathrm{~cm}$ thick) siltstones (Fig. 13.15). In west Lancashire the total thickness of the siltstones decreases towards the centre of the EISB, and the most commonly displayed sedimentary structure are desiccation cracks (Wilson \& Evans 1990). In the Thornton Mudstones (below the Preesall Halite; Fig. 13.4), which display the laminated facies to their best, the red and green-grey mudstones are arranged in a series of 12 cycles, which can be correlated from Walney island in SW Cumbria to the Blackpool area (Fig. 13.15) (Wilson 1990; Wilson \& Evans 1990). The upper part of the Bollin Mudstones (Fig. 13.4) of the Cheshire Basin shows a similar prominence of laminated mudstones as in the EISB, and a number of correlated red-green cycles (Arthurton 1980; Wilson 1993, 2003). The Byley Mudstone Member of the Cheshire Basin and the Coat Walls Mudstone Member, both of which overlie the Northwich and Preesall halites, have a lesser development of the laminated facies and are mostly blocky red mudstones (Arthurton 1980; Rees \& Wilson 1998). The Wych Mudstone Member of the Cheshire Basin, and its equivalent in the EISB and west Lancashire (Breckells Mudstone Member; Fig. 13.4), marks a complete return to deposition of the blocky red mudstone facies, with a few halite and anhydrite layers (Wilson 1990, 1993).

The Wilkesley Halite is known mostly from its type area in the Cheshire Basin where it is up to $404 \mathrm{~m}$ thick. It consists of beds of halite up to $26 \mathrm{~m}$ thick with numerous inter-beds of blocky red mudstones up to $12 \mathrm{~m}$ thick (Wilson 1990). In contrast to the Northwich Halite, it also contains sandstones up to $1 \mathrm{~m}$ thick, presumably representing short influxes from marginal successions, which may correlate with sandstone intervals in the Arden Sandstone Formation of the Midlands.

The overlying Branscombe Mudstone Formation is dominated by blocky red mudstones. It also locally contains thin greenish-grey mudstone intervals, thin sandstones, anhydrite nodules and veins, and halite veins (Wilson 1993).

\section{Economic Geology}

Offshore from Wales and NW England there are three groups of hydrocarbon discoveries hosted by Triassic rocks. The first comprises the various gas fields in the central part of the eastern Irish Sea region (North and South Morecambe, Dalton, Calder, Lom, Ormonde, Bains and the onshore Elswick field; Fig. 13.12) (Stuart 1993; Jackson et al. 1995) with the first discovery being the South Morecambe field in 1974. The second comprises the oil and gas producing fields further south in Liverpool Bay (Hamilton, Lennox, Douglas and onshore the now decommissioned Formby Oilfield); most of these offshore fields were discovered in the 1990s (Pearson 1995). The third comprise smaller, mostly oil discoveries and indications in the Cardigan Bay-Celtic Sea areas, many of which have yet to be fully developed. The Irish Sea gas discoveries comprise mainly Westphalian coal and shale source rocks underlying Triassic Sherwood Sandstone Group reservoirs, in turn overlain by Mercia Mudstone Group topseal, with local salt seals at faulted contacts. The Morecambe North and South discoveries were based on a large shallow domal anticline observed on seismic data, with the chief reservoir being the Ormskirk Sandstone. Acidic waters were crucial in dissolving carbonate and feldspar in the reservoir sandstone, prior to an early fill with liquid hydrocarbons during the Early Jurassic. Uplift and breaching occurred toward the end of the Jurassic and the present gas filling did not take place until Cretaceous and early Tertiary burial (Jackson et al. 1995). The Formby Oilfield (now decommissioned) is located over natural oil seepages, the products of which have been used since AD 1637. Production boreholes in the 1940s located oil in the Tarporley Siltstone Formation and 


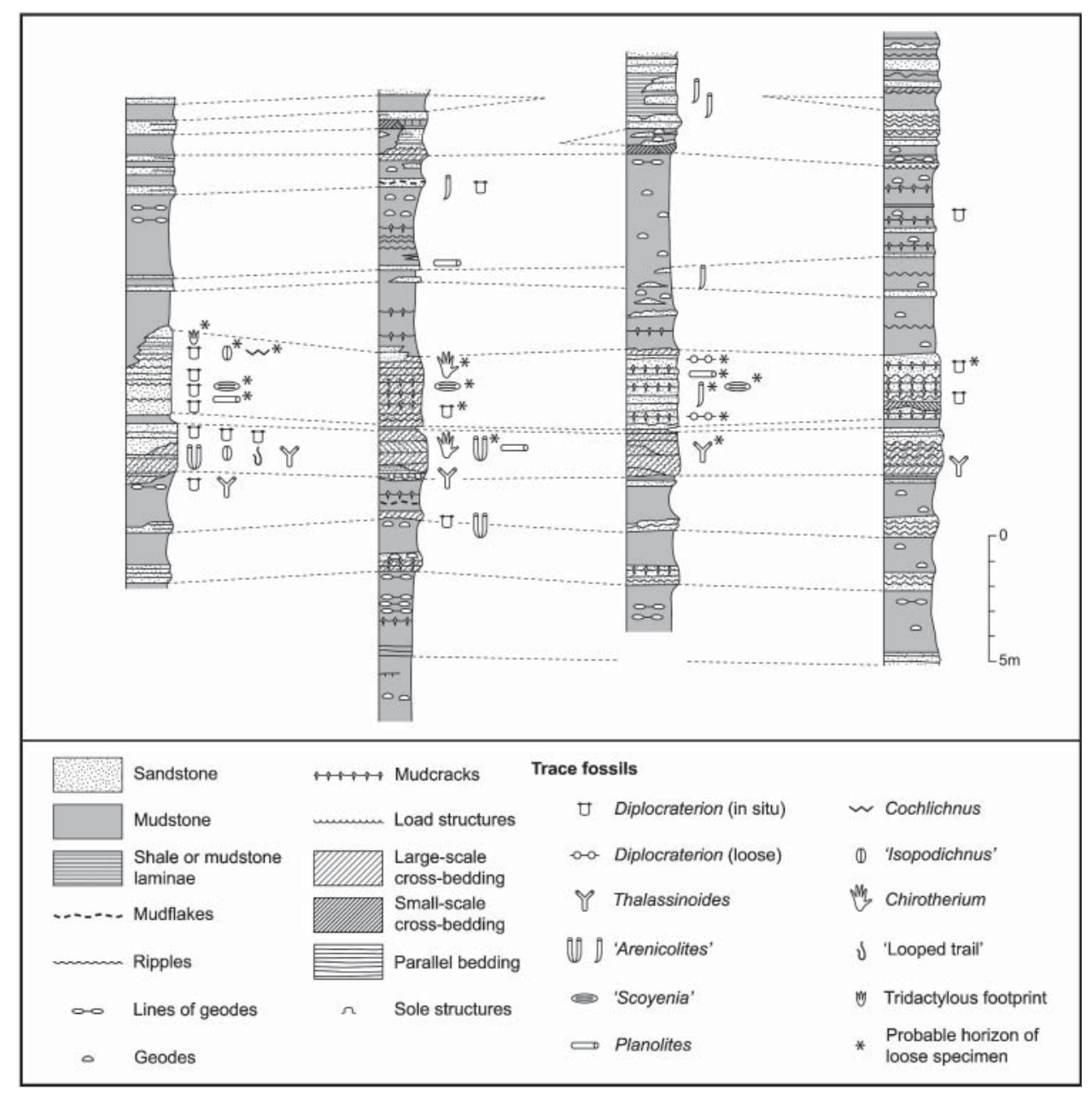

Fig. 13.14. Detailed sedimentary structures and correlation in the Tarporley Siltstone Formation at the Red Hill cutting, Cheshire. Modified from Ireland et al. (1978).

the uppermost Ormskirk Sandstone, in a faulted monocline. The Formby Oilfield contained a light crude oil, similar in composition to the East Midlands Carboniferous-hosted oilfields, which similarly are thought be derived from Namurian marine black shales (Jackson et al. 1995).

The Permo-Triassic sandstone aquifers are a heavily utilized groundwater resource in NW England, accounting for some $78 \%$ of licensed abstractions for public water supply from groundwater (Thewsey pers comm. 2005). The groundwater resources are segmented into a number of separate regions corresponding to the outcrop (Fig. 13.12). In Cheshire and around the Liverpool- Manchester area the Sherwood Sandstone is the major aquifer, although it is not a uniform unit for groundwater flow, most of the flow being restricted to depths down to $200 \mathrm{~m}$ below the surface, where the flow is primarily through fractures (Allen et al. 1997). Further north in west Lancashire and west Cumbria the intergranular hydraulic conductivity decreases, due to better cementation and the finer grain size of the Sherwood Sandstone, and fracture flow is the most significant effect on transmissivity (Allen et al. 1997). In northern Cumbria the absence of mudstone interbeds, the coarser-grained and less-cemented nature of the Kirklington Sandstone make it a better groundwater reservoir than the St Bees Sandstone. The Sherwood Sandstone in the Vale of Clwyd is the major aquifer in North Wales and is confined by a significant thickness of glacial till, giving rise to artesian conditions in the centre of the basin (Allen et al. 1997).

Salt $(\mathrm{NaCl})$ in the UK is currently extracted either using brine pumping ( $70 \%$ of production) or through mining methods which extract rock salt (Highley et al. 2004b). The only working mine in the Triassic in England is the Meadowbank Mine (near Winsford, Cheshire; Fig. 13.12), which utilizes several beds in the Northwich Halite Formation and since 1928 has been the UK major source of rock salt for road de-icing. Natural (or 'wild') brine in the subsurface is generated by ground water dissolution of salt beds. In the past these natural brines were utilized, but produced uncontrolled collapse of the resulting cavities, which produced hazardous surface subsidence. Thus in areas of old workings in Cheshire (around Northwich and Nantwich), some areas have been prone to sudden and catastrophic collapses of the ground, sometimes with buildings and roads collapsing into the hole. All solution mining is now by controlled pumping, in which a single borehole, with a triple tube system, combined with a compressed air blanket to limit upward dissolution, allows complete control of the brine extraction process and the size of the resulting cavity. The cavities produced are designed to withstand the weight of the overlying strata, so collapse does not occur (Highley et al. 2004b). Controlled brine pumping takes place at the Holford and Warmingham brine fields from the Northwich Halite (Fig. 13.12). In the past, controlled brine pumping also occurred at Preesall in Lancashire and near Barrow-in-Furness in Cumbria (Fig. 13.12). The stable cavities produced by rock salt mining and controlled brine pumping are themselves important economic assets for storage of natural gas, hydrogen, various organic chemicals, documents, and various types of waste.

In the past, sandstones from the Sherwood Sandstone Group in Cheshire, Shropshire and Cumbria were extensively used as 


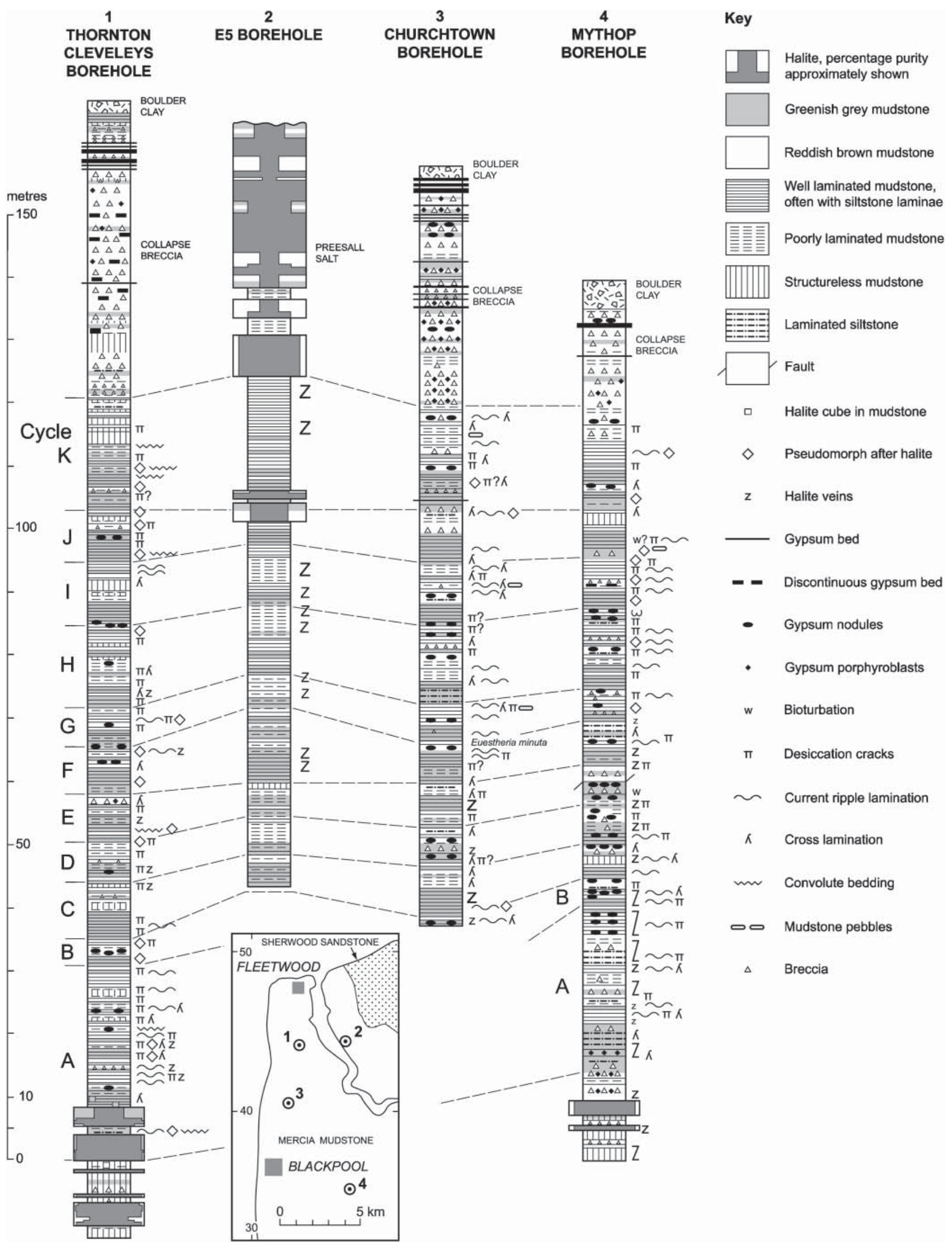

Fig. 13.15. The detailed correlation of cycles in the Thornton Mudstone Member (Mercia Mudstone Group) of West Lancashire. From Wilson \& Evans (1990). 
building stone, with over 20 sites in the Cheshire-Shropshire area alone (British Geological Survey 2001a). Now the only working sources of building stone are small quarries at St Bees in Cumbria (working the St Bees Sandstone), and quarries at Grinshill and nearby Myddle in Shropshire (Fig. 13.12), which utilize sawn white and red coloured sandstone from the Helsby Sandstone Formation, mostly for building restoration.

\section{Central England}

The most complete Triassic successions of central England are located in the basin depocentres of the Worcester Basin, Knowle Basin, Needwood Basin and Hinckley Basin (Fig. 13.6). The thickest succession preserved is that in the Worcester Basin where the Triassic is up to $1.5 \mathrm{~km}$ thick, but it thins considerably by onlap on to the adjacent Palaeozoic and Precambrian highs. This onlap appears to have been punctuated but progressive, so that the youngest units of the Triassic have the largest areal extent onto the basin margins (Sumbler et al. 2000).

Evidence of synsedimentary fault activity is abundant, with seismic lines demonstrating thickness changes of many hundreds of metres, with the thickest successions adjacent to major faults. These basins are generally aligned N-S, with fault-bounded Palaeozoic horsts. These predominantly N-S structures are terminated to the north by an array of approximately E-W aligned fault structures forming the north termination of the Needwood Basin against the Pennine High (Fig. 13.6) (Chisholm et al. 1988).

\section{Sherwood Sandstone Group in sequence TR1}

It is only within the deepest parts of the Worcester Basin that the boundary between the Permian Bridgnorth Sandstone and the Triassic Sherwood Sandstone Group may be conformable, through a mudstone succession that may be comparable to the Permian-Triassic transition interval in NW England and the southern North Sea (Sumbler et al. 2000).

Outside the centre of the Worcester Basin, the lowest beds of the Triassic are commonly poorly sorted breccias or conglomeratic sandstones, with a high content of locally derived, angular clasts. These basal breccias have been given a variety of local regional names (such as Moira and Hopwas breccias). The thinner breccia successions may represent regolith or pediment gravels, whereas the thicker deposits represent local alluvial fans shedding material from the highs into the basins. Their age is uncertain, and may be in part Permian probably extending into the Mid or Late Triassic, since locally they pass laterally into the Mercia Mudstone Group (Chisholm et al. 1988; Worssam \& Old 1988; Powell et al. 2000b).

The lowest beds of the Sherwood Sandstone Group are typically conglomerates, overlain by pebbly sandstones (Kidderminster, Polesworth and Cannock Chase formations; Fig. 13.3), which pass upwards to largely pebble free, crossstratified fluvial sandstones (Wildmoor Sandstone and Hollington Sandstone formations; Fig. 13.3). The Kidderminster Formation and its equivalents possess well-rounded pebbles dominated by vein quartz and quartzite, with lesser amounts of locally derived clasts. Petrography, heavy minerals, isotopic data from micas and derived fossils in clasts attest to the southerly-derived nature of these sandstones and their pebbles (Wills 1956; Mitchell \& Taka 1984; Jeans et al. 1993; Powell et al. 2000b). The regional spread of these pebbly sandstones indicates the establishment of a predominantly $\mathrm{N}$-directed braided fluvial system (Budleighensis river of Wills 1956), with far-travelled and well-rounded clasts. The thickness of the pebble-bearing units varies widely from $70 \mathrm{~m}$ in the centre of the Worcester Basin to 150 and $200 \mathrm{~m}$ in the Needwood and Hinckley basins. The Kidderminster Formation consists of a stacked succession of fluvial fining-up cycles, each with conglomeratic lower parts and either sandstone or mudstone tops. Wills (1970), in his seminal work on the English Midlands Triassic, proposed that regional correlations could be achieved in more basinal successions by grouping these cycles into bundles (which presumably reflect a climatic imprint), although his study has not been repeated using modern techniques. To the NE, in the Hinckley Basin, the abundance of mudstone intervals increases (Worssam \& Old 1988).

The pebble-bearing sandstones pass upwards through a gradational boundary into the overlying largely pebble-free Wildmoor Sandstone Formation (Fig. 13.3). This is an orangered coloured, fine-grained, commonly micacous sandstone, with a few red and green mudstone beds. The unit has a maximum thickness of some $120-250 \mathrm{~m}$ in the Worcester and Knowle Basins, and may be diachronous northeastwards into the conglomerate-bearing sandstones of the Hinckley and Needwood Basins, which probably indicates the local provenance of substantial proportions of the clastics from the London-Brabant High. However, the heavy mineral content suggests a similar southerly source like the underlying Kidderminster Formation (Powell et al. 2000b).

The thickness and preservation of the successions below the $\mathrm{H}$-unconformity was strongly controlled by both faulting and erosion prior to the deposition of the overlying Bromsgrove Sandstone. This appears to have restricted the older units of the Sherwood Sandstone Group to basin depocentres, and led to the removal of the Wildmoor Sandstone Formation in some areas (Wills 1970; Bridge et al. 1998). These younger units were perhaps deposited more widely on the basin margins in the Triassic, but have been removed during the uplift phase that is represented by the $\mathrm{H}$-unconformity. This situation is reminiscent of the sometimes large erosional truncation of the Dutch and German Middle Buntsandstein that occurs in the southern North sea below the Hardegsen unconformity (Geluk \& Röhling 1999).

\section{Sherwood Sandstone Group in sequence TR2-3}

The unconformity at the base of the Bromsgrove Sandstone Formation is particularly marked in the West Midlands, where it oversteps onto Lower Palaeozoic strata. In Warwickshire the basal beds locally contain wind-faceted dreikanter pebbles (Wills 1970). The formation exhibits fluvial fining-up cycles, 2-10 m thick, ranging from conglomerate (or breccia), with mudstone clasts at the erosive base, to mudstone at the top (Worssam \& Old 1988). The abundance of mudstone beds increases upwards, and in parts of the Hinckley Basin and south of Warwick, may comprise up to $30-40 \%$ of the formation (Old et al. 1987; Worssam \& Old 1988). The distinctive feature of the sandstones is their feldspar content, which can range up to $50 \%$, and coarser intervals may contain feldspathic pebbles (Wills 1970; Old et al. 1987; Powell et al. 2000b). The formation is up to $500 \mathrm{~m}$ thick in the Worcester Graben, and 200-300 m thick in the vicinity of Birmingham, with rapid thinning to $20-50 \mathrm{~m}$ onto basement highs. In its type area south of Birmingham, and also in boreholes in the Hinckley Basin, three subdivisions are recognized (Worssam \& Old 1988; Old et al. 1991; Powell et al. $2000 b$ ). The lower division (Burcot Member) is dominated by sandstones with common intervals of conglomerate containing mud-chip breccia, reworked caliche and vertebrate fragments. The middle division (Finstall Member) is dominated by sandstone-mudstone fining-up cycles, with common plant remains. The upper division (Sugarbrook Member-'waterstones' facies) is composed of argillacous mica-rich sandstones and siltstones, which may overstep onto Palaeozoic units. Both the middle and upper divisions locally contain sulphate nodules (Old et al. 1991), and mudstone beds may show evidence of brecciation due to pedogenesis and desiccation. The Finstall Member contains the most diverse fossil assemblages including, annelids, 
bivalves (Mytilus), arthropods (Crustacea and Scorpionida), amphibians, fish (Acrodus and Ceradotus) and reptiles, along with evidence of a diverse flora including lycopsids, sphenopsids, pteropsids, gymnosperms and conifers (Old et al. 1991). South of Birmingham, cross-stratification indicates sediment transport to the north and NE (Old et al. 1991), although on the flanks of the Worcester Basin the sandstone is interbedded with locally-sourced breccia showing that sediment transport was also locally derived from basement highs (Barclay et al. 1997).

\section{Mercia Mudstone Group}

The Mercia Mudstone Group in the Midlands is mostly known in detail from boreholes, and is up to about $650 \mathrm{~m}$ thick in the Worcester Basin with a similar thickness in the Hinckley Basin. It oversteps the older units of the Triassic to rest on the basement at basin margins, and probably totally covered some basement highs like Charnwood in the east. The subdivisions recognized by Elliot (1961) around Nottingham, can be identified in the Sidmouth Mudstone Formation of the Hinckley Basin and in adjacent parts of the West Midlands (Worssam \& Old 1988). These divisions progressively become indistinguishable westwards, so that the succession below the Arden Sandstone Formation is mostly undivided blocky red mudstones. Within southern and western parts of the Midlands the Arden Sandstone Formation (probably equivalent to Hollygate/Dane Hills sandstones of the East Midlands) can be identified, but this disappears northwards, and may be partly equivalent to the Stafford Halite in the Stafford Basin (Fig. 13.4).

A distinctive feature of the Mercia Mudstone Group in the Midlands is the presence of a number of sandstone or siltstone beds ('skerries'), which have provided locally useful markers for mapping by the Geological Survey and others. The thickest of these are up to about $10 \mathrm{~m}$, but many are less than $0.3 \mathrm{~m}$ thick. These intervals are pale brown-pale green in colour and range from siltstones to fine-grained sandstones. These are wellsorted, rich in dolomite, calcite or ankerite, with less common anhydrite and rare baryte (Old et al. 1987; Worssam \& Old 1988; Barclay et al. 1997), commonly with alternating carbonate-rich and quartz-rich laminae. Dolomite may form $40-95 \%$ of the matrix, and dolomitized ooids are rarely present (Worssam \& Old 1988). These coarser units are characteristically thin-bedded intervals, sometimes with wave/current ripples, planar and cross-lamination, with intervening thin red/green mudstone intervals. Mudcracks and halite pseudomorphs are also present.

The Arden Sandstone Formation is a unit of multicoloured mudstones with abundant discontinuous sandstones, which has

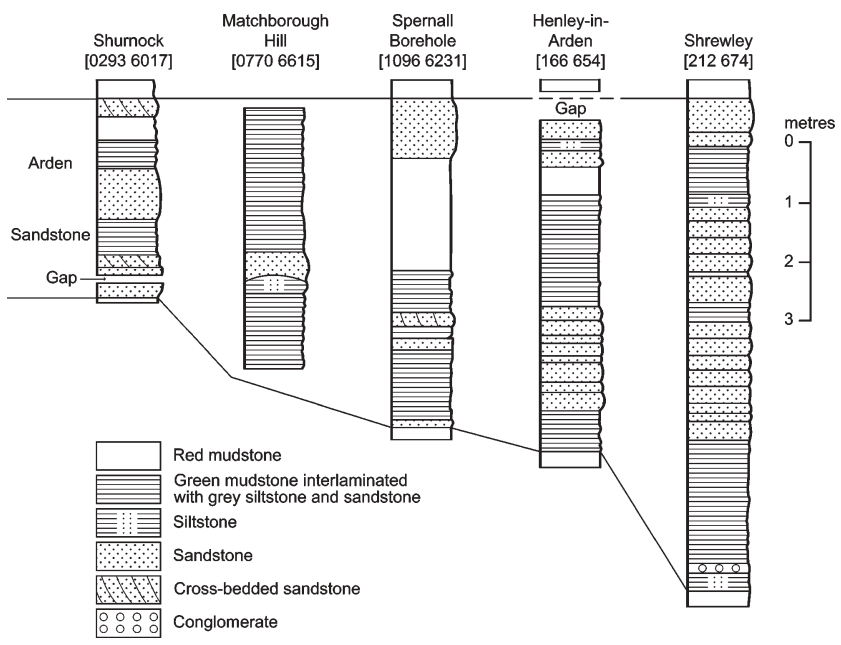

Fig. 13.16. Comparative sections in the Arden Sandstone Formation in its type area in Warwickshire (from Old et al. 1991). a type area in the South Midlands (Fig. 13.16). The thicker sandstone intervals in the Arden Sandstone Formation are cross-stratified and have erosional bases (Old et al. 1987; Barclay et al. 1997). The sandstone intervals are interbedded with dark green-grey laminated mudstones and siltstones, with subordinate purple and grey mudstones (Fig. 13.16). In some areas of the Midlands (i.e. deeper basins), the sandstone intervals may be reduced to little more than a few thin sandstone beds within a predominantly non-red mudstone succession. Cross-stratification measurements in the west Midlands suggests the Arden Sandstone detritus was transported by easterly- or NE-directed currents (Old et al. 1991). This and the distribution of the sandstone suggests that it may have been sourced from clastics shed from the Welsh High and the London-Brabant High.

\section{Economic Geology}

The Sherwood Sandstone Group to the west of the Birmingham Fault is a major aquifer, which largely acts as a single hydrological unit, although impermeable faults, finer-grained units and cemented layers within the sandstone may locally segment the aquifer both vertically and horizontally (Allen et al. 1997). Until the end of the 19th century, the city of Birmingham used the Sherwood Sandstone aquifer extensively for public supply; since then water reservoirs in Wales or the River Severn have been used. However, during years of drought on the River Severn (such as 1976, 1989 and 1995) the Triassic sandstone aquifer of north Shropshire is utilized to top-up the river for domestic and industrial supply in the West Midlands. Now in Birmingham almost all groundwater abstraction is for industrial use, although this use has been reducing since the 1970s. With the reduction of underground water abstraction there has been a steady rise in the height of the water table to the preindustrial levels (Ford \& Tellam 1994). This has caused flooding of cellars in domestic housing and created the potential for the groundwater to come into contact with contaminated ground, previously above the water table. Groundwater contamination around Coventry and Birmingham is particularly acute, with some of the Sherwood Sandstone aquifer compromised by leakage of light hydrocarbons and solvents into the subsurface (Ford \& Tellam 1994; Tait et al. 2004). Limited, agricultural water abstraction using wind-pumps does occur in the Midlands and SW England from the Arden Sandstone Formation, which is enclosed by Mercia Mudstone aquicludes and is thus less liable to pollution.

Historically, building stone from the Bromsgrove Sandstone Formation was locally important, with Norbury Church and Calke Abbey (both in Derbyshire) as some of the historically important buildings of this material (British Geological Survey 2001a). The loosely consolidated conglomerate-bearing lower intervals of the Sherwood Sandstone Group are still important sources of aggregate in the Midlands, with various locations being quarried (Fig. 13.12), such as at Tern Hill (near Market Drayton), Barnsley Lane east of Bridgenorth and several quarries SE of Cheadle in Staffordshire (Huntley Wood, Croxden and Freehay Quarries).

\section{Southwest England, South Wales and the offshore basins}

The outcrop of the Triassic in SW England stretches across Somerset and Devon and beneath the English Channel. Eastward extension is concealed by younger strata, but Triassic rocks in the subsurface extend eastwards to Purbeck and beyond (Butler 1998). Triassic is known from South Wales and its extension westwards in various offshore basins in the Bristol Channel, Western Approaches, southern Celtic Sea and Cardigan Bay (Evans 1990; Hamblin et al. 1992; Tappin et al. 1994). 
The onshore Triassic is divided into a number of predominantly E-W trending sub-basins, which include the PortlandWight Basin and the Bristol Channel Basin (Fig. 13.6) (Hamblin et al. 1992). In the western approaches the sub-basins of the Western Approaches Trough (the Melville, St Marys, SW Channel and Plymouth basins; Fig. 13.6) are elongated in a more SW-NW trend, reflecting the underlying Variscan structure. These contain Triassic successions which are relatively poorly known, but are similar in some ways to the Midlands and NW England Triassic, in that they contain relatively thick equivalents of the Sherwood Sandstone Group (Tappin et al. 1994). Minor syn-Triassic grabens and half-grabens throughout the greater SW English-Welsh area show variable orientations, probably as a result of underlying basement structural control (Miliorizos \& Ruffell 1998).

\section{Sherwood Sandstone Group}

In the Wessex Basin, the Sherwood Sandstone Group is divided into a lower conglomeratic unit, the Budleigh Salterton Pebble Beds and an overlying sandstone-dominated unit, the Otter Sandstone Formation (Fig. 13.3). This division also appears to be present in the Bristol Channel Basin, and the offshore St Georges Channel and South Celtic Sea basins (Fig. 13.6) (Tappin et al. 1994). The boundary between the Budleigh Salterton Pebble Beds and the underlying Aylesbeare Mudstone Group within the Wessex Basin is an unconformity (Holloway et al. 1989), which is most clearly apparent from seismic surveys and well data further east in the basin (Butler 1998). Within the deeper part of the basin in west Dorset an additional sandstone or siltstone interval (up to $70 \mathrm{~m}$ thick) rich in anhydrite rests conformably on the Budleigh Salterton Pebble Beds, which is unconformably overlain by the Otter Sandstone Formation (Fig. 13.3) (Butler 1998). Holloway et al. (1989) and Butler (1998) have suggested that the base Otter Sandstone unconformity seen on seismics is equivalent to the Germanic Basin $\mathrm{H}$-unconformity, although magnetostratigraphy suggests that the base of the Otter Sandstone Formation in the outcrops in $\mathrm{S}$. Devon corresponds to a slightly younger level (Hounslow \& McIntosh 2003). A prominent unconformity within the PermoTriassic successions in the Melville and Plymouth Bay basins (Western Approaches Trough) has been broadly equated with the Aylebeare Mudstone Group-Sherwood Sandstone Group boundary based on a similar seismic signature to that seen in the Wessex Basin (Evans 1990; Harvey et al. 1994).

The Sherwood Sandstone Group thins from up to $250 \mathrm{~m}$ in the western part of the Portland-Wight Basin to $170 \mathrm{~m}$ in the Wytch Farm area, and is absent east of the Isle of Wight and in the SE part of the English Channel (Hamblin et al. 1992). In the western Approaches Trough, the Sherwood Sandstone Group ranges from over $900 \mathrm{~m}$ in the Melville Basin to a more typically thickness of $100-300 \mathrm{~m}$ in other sub-basins in the Trough (Evans 1990). Depositional continuity from the Wessex Basin to the offshore St Georges Channel and South Celtic Sea Basins was probably not maintained through the Bristol Channel Basin, which acted as a high until deposition of the Mercia Mudstone Group (Tappin et al. 1994).

\section{Budleigh Salterton Pebble Beds - sequence TRI}

The Budleigh Salterton Pebble Beds (Fig. 13.17a) are composed of ortho-conglomerates and subordinate sandstones and are the deposits of a braidplain or wet alluvial fan (Smith 1990; Smith \& Edwards 1991). Magnetostratigraphy suggests the Budleigh Salterton Pebble Beds represent only a short interval of the Early Triassic (Hounslow \& McIntosh 2003). The quartzite clasts within the Budleigh Salterton Pebble Beds are famous for containing an exotic Ordovician and Devonian brachiopod fauna from Brittany and Normandy (Cocks 1993). The beds also contain tourmalinized hornfels and quartz-porphry clasts, and an Armorican-derived heavy mineral suite (Thomas 1909;
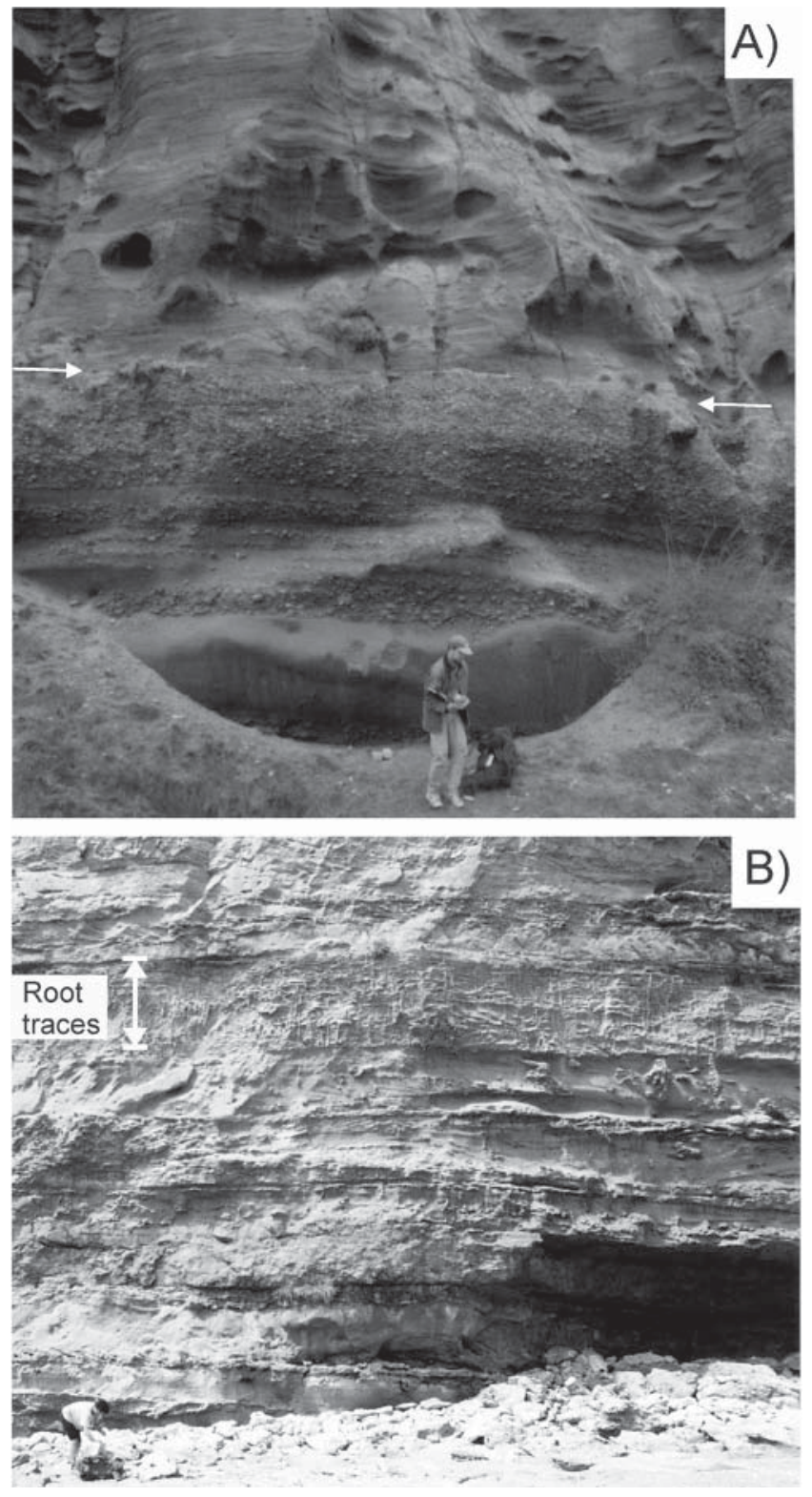

Fig. 13.17. (a) H-disconformity (arrowed) between the Budleigh Salterton Pebble Beds and the Otter Sandstone Formation. At this location the first beds in the Otter Sandstone are dune-bedded sandstones that occupy the upper part of the photo. There is a thick impersistant sandstone interval in this section of the upper most part of the Budleigh Salterton Pebble Beds; Budleigh Salterton, Devon. (b) Differential weathering of vertical rhizoconcretions from Unit B of the Otter Sandstone Formation, that are particularly marked in one bed (arrowed), Coal Beach, near Budleigh Salterton. People used for scale.

Wills 1956; Campbell-Smith 1963; Jeans et al. 1993). The Budleigh Salterton Pebble Beds represent the deposits of a river system which drained the Armorican land-mass located in western France and the southern English Channel, and transported exotic clastics northwards into the Wessex Basin (Holloway et al. 1989; Smith \& Edwards 1991). Within the northerly part of the Budleigh Salterton Pebble Beds outcrop in Devon, locally derived Carboniferous and Devonian sandstone and limestone clasts together with palaeocurrent measurements show that tributaries from upland areas to the west in Cornubia also contributed locally (Smith \& Edwards 1991).

A horizon of wind-faceted pebbles (ventifacts) is regionally important at the top of the Budleigh Salterton Pebble Beds (Leonard et al. 1982; Smith \& Edwards 1991), and is associated 
in the coastal outcrops with a desert palaeosol (Fig. 13.17a) (Wright et al. 1991), which appears to indicate a major hiatus. Seismic evidence in the central and western parts of the Wessex Basin suggests that this major unconformity at the base of the Otter Sandstone Formation locally truncates faults in the underlying succession (Butler 1998).

Conglomerate-bearing sandstones equivalent with the lower part of the Sherwood Sandstone Group (of the Wessex Basin) are known from the Melville Basin of the Western Approaches Trough, the Wessex Basin, the South Celtic Sea and the St Georges Channel basins (up to $75 \mathrm{~m}$ thick). It may be that this equivalent of the Budleigh Salterton Pebble Beds is only present in more strongly subsiding sub-basins, perhaps indicating the original restriction of deposition to palaeovalleys in the Early Triassic landscape, or major truncation at the H-unconformity.

\section{Otter Sandstone Formation-sequence TR2-3}

The Otter Sandstone Formation forms most of the Sherwood Sandstone Group within the Wessex Basin, and largely consists of stacked fluvial channel sandstones, with minor mudstones and some aeolian sandstones. At outcrop in south Devon the age of the Otter Sandstone Formation ranges from the latest Early Triassic to near the Anisian-Ladinian boundary (Hounslow \& McIntosh 2003). Farther east in the Wessex Basin around the Wytch Farm Oilfield (Fig. 13.12), seismic evidence suggests the upper part of the Sherwood Sandstone Group passes westwards into the Mercia Mudstone Group, indicating that the upper boundary of the Sherwood Sandstone Group is probably diachronous (Butler 1998).

Within the coastal outcrop in Devon the Otter Sandstone Formation has been divided into four units, A, B, C and the Pennington Point Member (Hounslow \& McIntosh 2003; Gallois 2004). These loosely define an overall fining-up succession, which is also typical of the Otter Sandstone in the Wytch Farm area (Lott \& Strong 1982; Holloway et al. 1989; McKie et al. 1998; Svendsen \& Hartley 2001, 2002). In the coastal outcrops, the oldest parts of the Otter Sandstone Formation are a heterogeneous unit (c. $20 \mathrm{~m}$ thick), consisting of a basal aeolian sandstone overlain by non-calcrete bearing fluvial channel sandstones (Fig. 13.17a). At outcrop these pass upwards into Unit B of the Otter Sandstone Formation, characterized by multistorey stacked channel sandstones, with a paucity of lacustrine or floodplain mudstones. Unit B contains abundant reworked calcrete (from rhizoconcretions; Purvis \& Wright 1991) and mudstone clasts in the basal lags of channel sandstones. In situ calcretes common in unit B are seen to be both vertical calcrete rhizoconcretions formed around the taproots of phreatophytic plants (Fig. 13.17b), and horizontal sheets of calcrete formed at contemporary water table surfaces (Purvis \& Wright 1991). Reptilian remains are mostly found within the channel lags, which include rhynchosaurs, temnospondyl amphibians and fish, most commonly comprising disarticulated skull elements (Milner et al. 1990; Benton 1997; Spenser \& Storrs 2002).

The upper part of the Otter Sandstone Formation (Unit C) has more abundant mudstone and sandstone filled abandoned channels, with lesser amounts of in situ and reworked calcrete, perhaps representing a higher sinuosity river system (Svendsen \& Hartley 2001). Minor aeolian sandstones also occur in the upper part of the Otter Sandstone at Wytch Farm or are known from marginal areas (McKie et al. 1998; Edwards 1999). Gallois (2004) has referred the uppermost unit in the Otter Sandstone at outcrop to the Pennington Point Member. This is a succession of fluvial channel and sheetflood sandstones interbedded with numerous red mudstones, whose sandstones lack reworked calcrete, and may be heavily channelized. This is similar in character to the uppermost units in the Otter Sandstone Formation at Wytch Farm that are interpreted as strongly lacustrine in character (McKie et al. 1998).
In the Burton Row borehole in Somerset Whittaker et al. (1985) divided the equivalent of the Otter Sandstone Formation into two units on the basis geophysical logs, a lower sanddominated interval and an upper mudstone-rich interval. This division is also apparent in wells in the St Georges Channel and South Celtic Sea Basins (Tappin et al. 1994). This two fold division may correspond to the Unit $\mathrm{A}+\mathrm{B}$ and Unit $\mathrm{C}+$ Pennington Point Member division known from the Devon outcrop sections, perhaps implying a regional response to a climatic event, or a consistent regional relaxation phase in basin tectonics. Miospore dating of the Sherwood Sandstone Group in the offshore basins suggests the age of the upper boundary of the Sherwood Sandstone Group may range from Anisian to Ladinian (Tappin et al. 1994).

\section{Mercia Mudstone Group}

The Mercia Mudstone Group (below the Blue Anchor Formation) within the Wessex and Bristol Channel basins is divided into three units, comprising upper and lower red-mudstone dominated units, separated by a multicoloured mudstone unit containing sandstone intervals (Arden Sandstone Formation; Fig. 13.4), which in basin depocentres contains halite (Gallois 2003). The Sidmouth and Branscombe Mudstone formations, which have a type area in south Devon, are dominated by blocky red mudstone and represent most of the Mercia Mudstone Group at outcrop in SW England. It is only within the multicoloured mudstone unit (some $30 \mathrm{~m}$ thick) that substantially different environmental conditions developed.

In the cliffs east of Sidmouth the Sidmouth Mudstone Formation comprises blocky red mudstones, with a few interbeds of green mudstones and siltstones, and some thin sandy siltstones. Gypsum nodules and veins are particularly common in the upper part of the succession (Gallois 2001). The Sidmouth Mudstone Formation may correspond to lithological units A-C defined by Lott et al. (1982) from gamma ray and sonic velocity measurements in boreholes in the Wessex Basin. Unit C includes substantial quantities of halite in the deeper parts of the basin, which Gallois (2003) has instead correlated to his Dunscombe Mudstone Formation (=Arden Sandstone Formation). Inter-borehole correlation is made difficult by listric faults that become bedding-parallel in the halite units in the Mercia Mudstone Group (Butler 1998).

The Arden Sandstone Formation at outcrop on the south Devon coast near Weston Mouth is a distinctive unit of interbedded greenish-grey, purple grey, red-brown and dark grey mudstones and siltstones with several sandstone beds. It contains a rich diversity of macroscale sedimentary structures including lamination, cross-lamination, invertebrate trace fossils, mudcracks, mudstone rip-up clasts, brecciated beds and immature palaeosols (Fig. 13.7c). Some of the brecciated beds are penecontemporaneous halite collapse breccias (Gallois 2003). Strata equivalent to part or all of the Arden Sandstone Formation in west Somerset display strongly incised fluvial channels, indicating easterly directed-palaeoflow away from the margin of Cornubia (Ruffell 1991). Simms \& Ruffell (1990) interpreted the increased fluvial inputs in the Carnian as representing a period of increased rainfall. This would certainly accord with the widespread development of the Arden Sandstone Formation in the Midlands.

The predominantly red-mudstones of the Branscombe Mudstone Formation are interrupted by minor thin $(<1 \mathrm{~m}$ thick) sandstones, and a major interval of gypsum, the Red Rock Gypsum Member (Gallois 2001). This same unit is also present in the subsurface farther east (Gallois 2001), and may be the equivalent of the Yate sulphate bed in the Bristol region, the Tutbury Gypsum of the East Midlands and parts of the Keuper Anhydrite in the southern North Sea. At St Audrie's Bay in north Somerset, the uppermost $99 \mathrm{~m}$ of the Branscombe Mudstone Formation comprise red-brown dolomitic mudstones and 
siltstones with irregularly interbedded, green or greenish-grey mudstones and pale dolomites, with rare desiccation cracks, wave ripples and burrows (Talbot et al. 1994; Hounslow et al. 2004). The former presence of evaporates (sulphates) is indicated by dissolution voids and small collapse structures. The upper parts of the Branscombe Mudstone Formation can also be seen in South Wales, west of Penarth, and at Aust Cliff, near Bristol (Curtis 1982; Waters \& Lawrence 1987). In north Somerset, the upper part of the Branscombe Mudstone has been correlated, using magnetostratigraphy, with the mid-late Norian conodont-bearing successions of the Tethys (Hounslow et al. 2004).

Although the presence of gypsum is a persistent feature of the Branscombe Mudstone Formation in borehole cores, the preservation of gypsum at outcrop is quite variable over distances of several hundred metres. This can be seen readily at Aust Cliff (near Bristol) and Seven Sisters Bay (near Penarth), where substantial beds of gypsum pass laterally within a few metres into green mudstones.

The tripartite subdivision of the Mercia Mudstone Group in the Wessex and Central Somerset basins can be applied to the Mercia Mudstone Group in the St Georges Channel, South Celtic Sea and Bristol Channel basins (Tappin et al. 1994). The middle division (equivalent to the Arden Sandstone Formation) contains substantial quantities of interbedded evaporates, and may comprise up to $70 \%$ of the thickness of the Mercia Mudstone Group in some wells in the deeper parts of the basins. The age control that is available in these offshore basins implies that the majority of the halite-bearing middle unit is Carnian in age, although in some boreholes it may extend into the Norian, and possibly down into the Early Triassic (Tappin et al. 1994).

\section{Economic Geology}

The Wytch Farm and Wareham oilfields (discovered in 1973) extends beneath Poole Harbour (and surrounding lands), Studland in Dorset and offshore below eastern Bournemouth Bay. Along with the Gannet D satellite field discovered in 1987 (Fig. 13.12), these fields are estimated to contain some 65 million tonnes of oil and are expected to remain productive until about 2035. The oilfield contains two reservoirs, the principal one ( $90 \%$ of reserves) being the Sherwood Sandstone Group, with production also from the Jurassic Bridport Sands. The Sherwood Sandstone Group reservoir is segmented by extensional faults which are oriented E-W and are influenced by underlying Variscan thrusts (Bowman et al. 1993). Oil was generated in the downfaulted Lias to the south of Wytch Farm in the Late Cretaceous and migrated upwards and northwards to its present position. The best quality reservoir is found in the lower half of the Sherwood Sandstone reservoir, interpreted by McKie et al. (1998) as a floodplain-sheetflood facies that was successively incised by stacked, channel-fill sandstones.

The main development of groundwater resources in the Permo-Triassic aquifers in SW England are in the Sherwood Sandstone, mostly in the Otter Valley north of Budleigh Salterton. Here the aquifer is about $150 \mathrm{~m}$ thick, and may be locally separated into a number of flow units by mudstones horizons near the boundary of the Otter Sandstone-Budleigh Salterton Pebble Beds and within the Otter Sandstone. Potable water in this aquifer is limited to within $5 \mathrm{~km}$ east of the basal outcrop of the Mercia Mudstone by high dissolved solids (Allen et al. 1997).

The Budleigh Salterton Pebble Beds are utilized as a source of sand and gravel in Devon with quarries at Blackhill, Hillhead and Whiteball exploiting the full stratigraphic thickness of the deposit (Fig. 13.12). Small supplies of building and walling stone are derived from the Budleigh Salterton Pebble Beds, worked at Capton near Williton (Somerset), and Langport Member limestones ('white Lias') from the Stowey Quarry near Bishop Sutton (Avon).
In the past, salt from natural brines was extracted from the Somerset salt field, hosted in the Mercia Mudstone Group, and a similarly large deposit of salt occurs in Dorset, buried at greater depth (Fig. 13.12). In the upper parts of the Branscombe Mudstone Formation, celestite (strontium sulphate) was worked for over 100 years, extracted from shallow pits mostly to the west of Yate (north of Bristol), from the Yate sulphate bed. Production ceased in the mid 1990s, but this area was once the world's leading producer of celestite.

\section{Blue Anchor Formation}

During deposition of the Mercia Mudstone Group there was a progressive loss, in younger strata, of regional dissimilarities which first makes its mark during deposition of the Branscombe Mudstone Formation, which everywhere in the UK is dominated by red mudstones with gypsum and anhydrite. However, it is unclear if the onset of Branscombe Mudstone deposition is the same throughout England and Wales, since this formation lacks age control apart from magnetostratigraphy in north Somerset and some sporadic miospore dating (Warrington 1981, 1984; Hounslow et al. 2004).

At the type area of the Blue Anchor Formation in north Somerset, the base is placed at the top of the highest major red mudstone bed (Whittaker \& Green 1983; Warrington \& Whittaker 1984) (Plate 25). In north Somerset it is divided into the Rydon and overlying Williton members (Mayall 1981), where the Rydon Member ( 29 m thick) comprises the 'tea green marls' and most of the overlying 'grey marls' of older terminology (Richardson 1911; Warrington et al. 1980; Warrington \& Ivimey-Cook 1995) (Fig. 13.18). Here the 'tea green marls' include a succession of interbedded, green, dark grey and black dolomitic and calcitic mudstones, whereas the overlying 'grey marls' are dominated by interbedded pale grey-black dolomitic mudstones and dolostones (Plate 25). A prominent dolostone with solution cavities marks the base of the 'grey-marls' (Whittaker \& Green 1983). Laminated silty mudstone beds, brecciated beds and mudcracked intervals are also present. In the subsurface and at Blue Anchor the Rydon Member contains gypsum nodules and beds, but at St Audrie's Bay, and in the Blue Anchor Formation at Penarth (South Wales; Waters \& Lawrence 1987) solution features and collapse structures reflect the former presence of evaporite minerals.

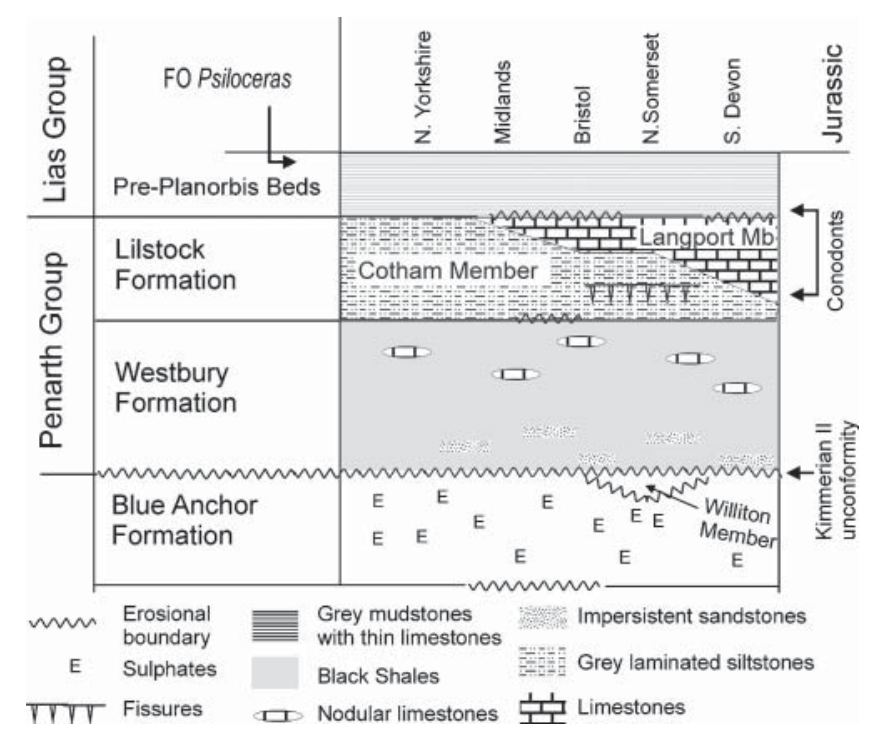

Fig. 13.18. Lithostratigraphy and regional variations in the Blue Anchor Formation and Penarth Group. FO, first occurrence. 
In other areas, such as South Wales, south Devon, Avon and Gloucestershire, the Blue Anchor Formation includes substantially less of the 'tea green marls' type of lithology. In these areas the green mudstones, with interbedded red mudstones are included within the Branscombe Mudstone Formation (Old et al. 1987, 1991; Gallois 2001). In South Wales the Blue Anchor Formation also includes thin $(<0.3 \mathrm{~m}$ thick) intervals of red mudstone. Locally, in places such as Warwickshire and at basin margin locations such as in South Wales, the Blue Anchor Formation has an erosive relationship to the underlying strata (Old et al. 1987; Water \& Lawrence 1987; Barclay et al. 1997), or may overstep onto pre-Triassic units. Hence, the Blue Anchor Formation probably represents a separate tectonostratigraphic unit of sequence TR2-3, whose base may equate with one or more of the sequence boundaries at about this level in the southern North Sea.

In north Somerset the Williton Member (Mayall 1981; Edwards 1999) comprises the highest beds of the former 'Grey Marls' which thickens westwards into the Bristol Channel Basin (Fig. 13.18). It represents the first truly marine deposit of the UK Upper Triassic, in that it consistently contains marine microplankton and macrofauna (Warrington 1981; Warrington \& Whittaker 1984). The Williton Member comprises grey silty shales with fine, flaser-bedded silts and sands and is overlain disconformably by the Westbury Formation (Penarth Group). However, it cannot be identified outside the north Somerset region, probably due to its erosion in other areas prior to the deposition of sequence TR4 (Penarth Group). Chronostratigraphic dating of the Blue Anchor Formation is problematic, mainly because the criteria that should be used to define the base of the Rhaetian have not been decided, even though magnetostratigraphy from this unit allows correlation with successions in other parts of the world that have been loosely referred to as Rhaetian or late Norian (Hounslow et al. 2004).

\section{Triassic basin margin deposits}

The nature of the margins of the Mid and Late Triassic basins are generally poorly understood, because for the most part the marginal deposits are poorly preserved. Locally-derived breccias, commonly matrix-supported (both sandstone and mudstone matrix) are characteristic of some regions (Chisholm et al. 1988; Worssam \& Old 1988). These are thin deposits, laterally very variably, that have been interpreted as local alluvial fans, or fossil screes. Brookfield (2004) considered similar deposits as regolith and pediment channel deposits on an exposed desert surface, much like in the present day Egyptian desert. Around Charnwood in the East Midlands, the Mercia Mudstone abuts directly against basement, with a few metres of laterally intervening brecciated basement. The basement outcrops show features indicating in situ weathering, and the mudstones may be cross-stratified (Worssam \& Old 1988), perhaps suggesting that aeolian deposition from mud aggregates, rather than alluvial processes, was most important in covering these basement outcrops.

In South Wales and in parts of the Bristol region, marginal facies of the Mercia Mudstone Group lacustrine basins are preserved, and provide the opportunity of understanding the interface zone between Triassic 'upland areas' and the lacustrine systems (Fig. 13.19). In both these regions the shore-zone deposits pass within a short distance into blocky red dolomitic mudstones of the Branscombe Formation, or into the greygreen mudstones of the Blue Anchor Formation (Waters \& Lawrence 1987). In South Wales, there are broadly two groups of marginal facies. Around Barry Island, the Wenvoe Valley, and around Bridgend, lacustrine shore-zone sediments dominate, which are composed of breccias, conglomerates, calcareous sandstones and siltstones, with subordinate fenestral and cryptalgal carbonates. The carbonates generally occur

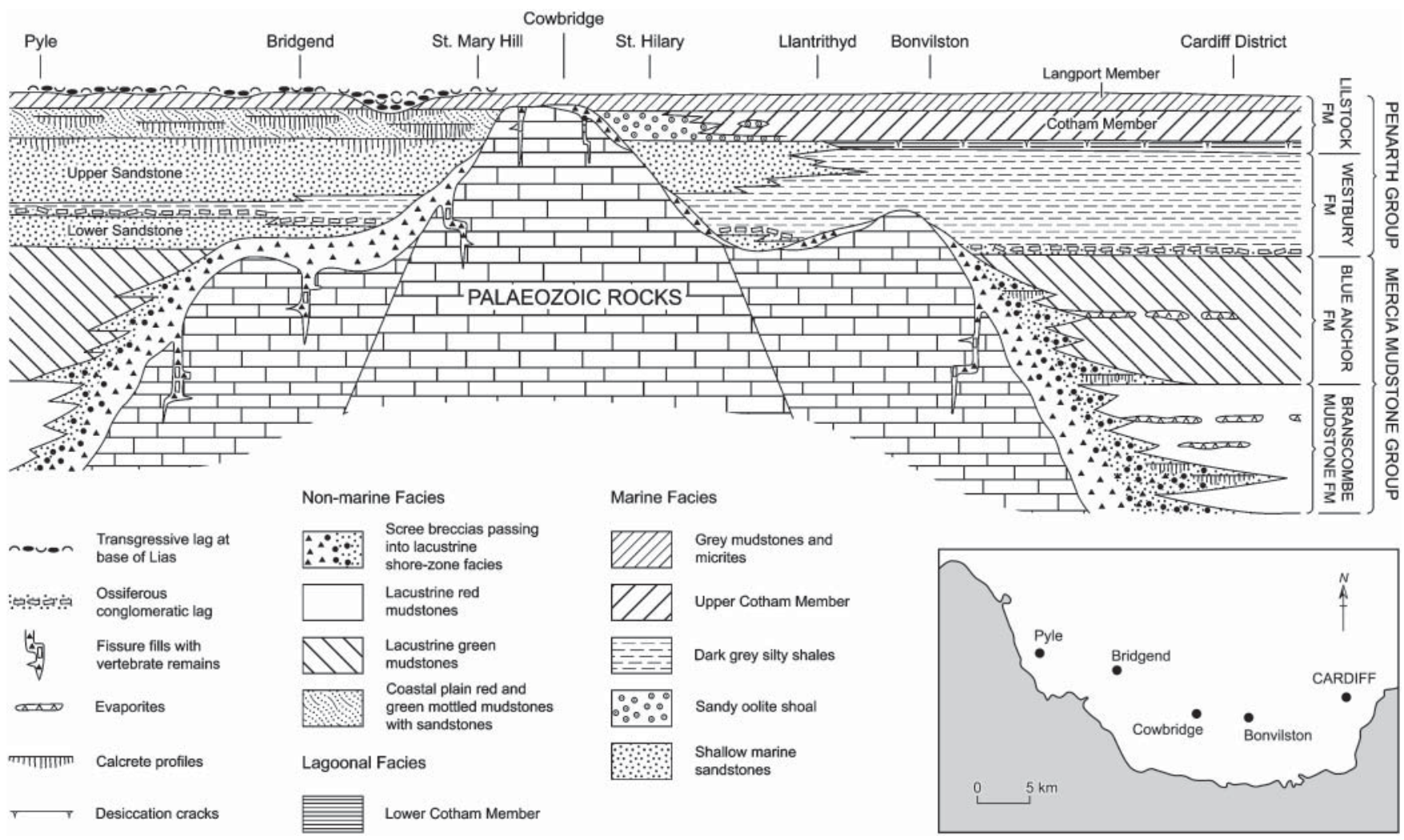

Fig. 13.19. The distribution of marginal facies in the Late Triassic around the 'Cowbridge Island' in South Wales. In the Mercia Mudstone Group, alluvial fan breccias and shore-zone lacustrine facies are limited to a thin zone at the basin margin. Modified from Waters \& Lawrence (1987). 
basinward of the clastics but in depositional continuity with the Branscombe Mudstone or Blue Anchor formations (Fig. 13.19). Nodular calcretes and replaced evaporates also occur (Tucker 1978; Waters \& Lawrence 1987; Wilson et al. 1990). The carbonates are interpreted to have formed in a lowsalinity lacustrine system (Leslie et al. 1992). These deposits formed around small contemporaneous islands composed of Carboniferous limestones and Devonian sandstones (Tucker 1978; Waters \& Lawrence 1987). These islands had up to five wave-cut terraces and notches, and the deposits can within $10 \mathrm{~m}$ pass laterally into red and green mudstones with evaporites (Leslie et al. 1992). The marginal facies of the Blue Anchor Formation display a distinctively different lithology, being dominated by pale grey limestone-chip breccias and conglomerates, interbedded with pale brown and green calcitic and dolomitic mudstones with fenestral carbonates (Wilson et al. 1990).

South of Cardiff the lacustrine shore-zone deposits in turn pass northwards into a SSE-NNW-oriented palaeovalley filled with a series of breccias, fluvial sandstones and conglomerates, with local development of calcrete and dinosaur footprints (Tucker \& Burchette 1977; Tucker 1978; Waters \& Lawrence 1987). These deposits represent deposition in alluvial fans, augmented by sheet-floods during periods of intense rainfall (Tucker 1978), which transported sediment eastwards into the basin (Fig. 13.19). The interbedding of the lacustrine shore-zone carbonates with alluvial fan deposits, together with the wavecut platforms and structures indicating desiccation, attest to the fluctuating level of the Late Triassic lake system.

In the Bristol region there is a similar succession of alluvial fan-like deposits (dolomitic conglomerate) composed of a variety of breccias, conglomerates and sandstones (Kellaway \& Welch 1993). In the Clevedon area these occur with shore-zone clastics, including ooid-bearing deposits, which in some cases represent cementation in wave-dominated beach systems (Milroy \& Wright 2000). The age of the ooid-bearing carbonates described by Milroy \& Wright (2000) is less than certain and these may be coeval with the Blue Anchor Formation. The alluvial-fan deposits vary greatly in thickness due to both filling of probable palaeotopography and faulting. The nature and disposition of these marginal deposits in both South Wales and the Bristol region are perhaps the clearest evidence that during deposition of the upper part of the Mercia Mudstone Group, substantial water bodies existed, which have left little apparent imprint on the blocky red mudstones which dominate the Mercia Mudstone Group.

\section{The Penarth Group}

There were major environmental changes in England and Wales, and the rest of the world, during the transition from the Late Triassic to the Jurassic. The extinctions in Triassic biota and flora that precede the start of the Jurassic are one of the five major extinctions in Earth's history (see below: Hallam 2002; Tanner et al. 2004). The Rhaetian seems to have been a time of globally low sea level (Hallam \& Wignall 1999), since there are few marine sections in the world that record an uninterrupted transition from the Rhaetian into the Jurassic. England and Wales is fortunate in this respect, in that a relatively complete record of the changes from the latest Triassic into the Jurassic is preserved in the sediments. Latest Triassic environmental changes are broadly reflected in England and Wales by the transition from the red 'desert' mudstones of the Branscombe Mudstone Formation to the lacustrine-dominated sediments of the Blue Anchor Formation (Plate 25), then to marine conditions, which generally began with the Penarth Group (Fig. 13.18).

The erosional unconformity between the Penarth Group and the underlying Blue Anchor Formation is universally recognized through England and Wales, and is the Kimmerian II unconformity of Zeigler (1990), widely recognized through northern Europe (Gianolla \& Jacquin 1998; Goggin \& Jacquin 1998). In the UK this unconformity represents a substantial time gap and has probably removed a variable proportion of the Blue Anchor Formation (Hounslow et al. 2004). The Kimmerian II unconformity heralds a major change to deposition of black marine shales of the Westbury Formation of the Penarth Group throughout England and Wales, similar to that seen throughout many basinal areas of northern and central Europe (Geluk 2005b).

The Westbury Formation consists of dark grey and black shaly mudstones and subordinate calcareous silty mudstones and grey, concretionary limestones. Also present are thin, waverippled sandstones, some of which are pebbly and contain remains of fish and other vertebrates, forming tempestite 'bonebeds' (Warrington \& Ivimey-Cook 1995; Swift \& Martill 1999) probably as a result of monsoon storms (MacQuaker 1994b).

The Cotham Member of the Lilstock Formation comprises pale grey-green calcareous mudstones with subordinate limestones, siltstones and sandstones commonly with mudcracks (Fig. 13.18). Stromatolites occur in these deposits around Bristol (Mayall 1983; Swift 1999). A prominent bed of disturbed sediment commonly occurs in the middle of the member, below a bedding surface penetrated by deep shrinkage cracks (Mayall 1983; Hesselbo et al. 2002; Simms 2003). This surface shows local evidence of erosion, although the deep shrinkage cracks are limited to the Bristol Channel region, and do not occur in the Cotham Member on the south Devon coast (Mayall 1983). The Cotham Member formed in shallower water than the underlying Westbury Formation and contains a marine microflora and fauna and was deposited largely in marine environments (Warrington 1981; Swift 1999). The origin of the disturbed bed in the Cotham Member has been variously interpreted as due to local seismic disturbance or shock waves from a bolide impact (Mayall 1983; Simms 2003). Hesselbo et al. (2004) have proposed that this shrinkage-cracked bed represents a sea level lowstand, with the overlying units (into the Jurassic) representing a transgressive system tract (Fig. 13.20).

The overlying Langport Member varies considerably on a regional scale. In southern England it is represented by microspar and peloidal limestones, that are commonly laminated and formed in shallow lagoons in warm, carbonate-rich marine water. These are well exposed in Pinhay Bay at Lyme Regis, where they display breccias, slumped units and micritized cross-stratified grainstone beds (Wignall 2001b; Hesselbo et al. 2004). Farther north this limestone facies is progressively replaced by siltstones and mudstones, until the Nottinghamshire area northwards, beyond which the Lilstock Formation is entirely represented by siltstones and mudstones (Fig. 13.18) (Swift 1995b).

Marginal facies of the Penarth Group are known at relatively few locations, which include boreholes on the northern margin of the London-Brabant High (Warrington et al. 1980; Cameron et al. 1992), in North Wales (Mochras borehole) and at Vallis Vale near Frome (Swift 1999). The most extensive marginal deposits are those around Bridgend in South Wales. Here, up to $14 \mathrm{~m}$ of sandstones overlain by $6 \mathrm{~m}$ of mostly green, red and buff-coloured mudstones form the lateral equivalent of the Westbury and Lilstock Formations respectively (Fig. 13.19) (Wilson et al. 1990). The sandstones equivalent to the Westbury Formation consist of an upper and lower unit separated by black mudstone, with the upper sandstone locally overstepping onto older rocks. The sandstone contains low-angle and hummocky cross-stratification with common conglomeratic lags, indicating deposition in a storm-dominated shoreface environment. The marginal facies of the Cotham Member comprises green, red and buff calcareous mudstones, with siltstone and sandstone lenses. Both the top of the upper sandstone and the Cotham Member equivalent units display dolomitic calcretes 


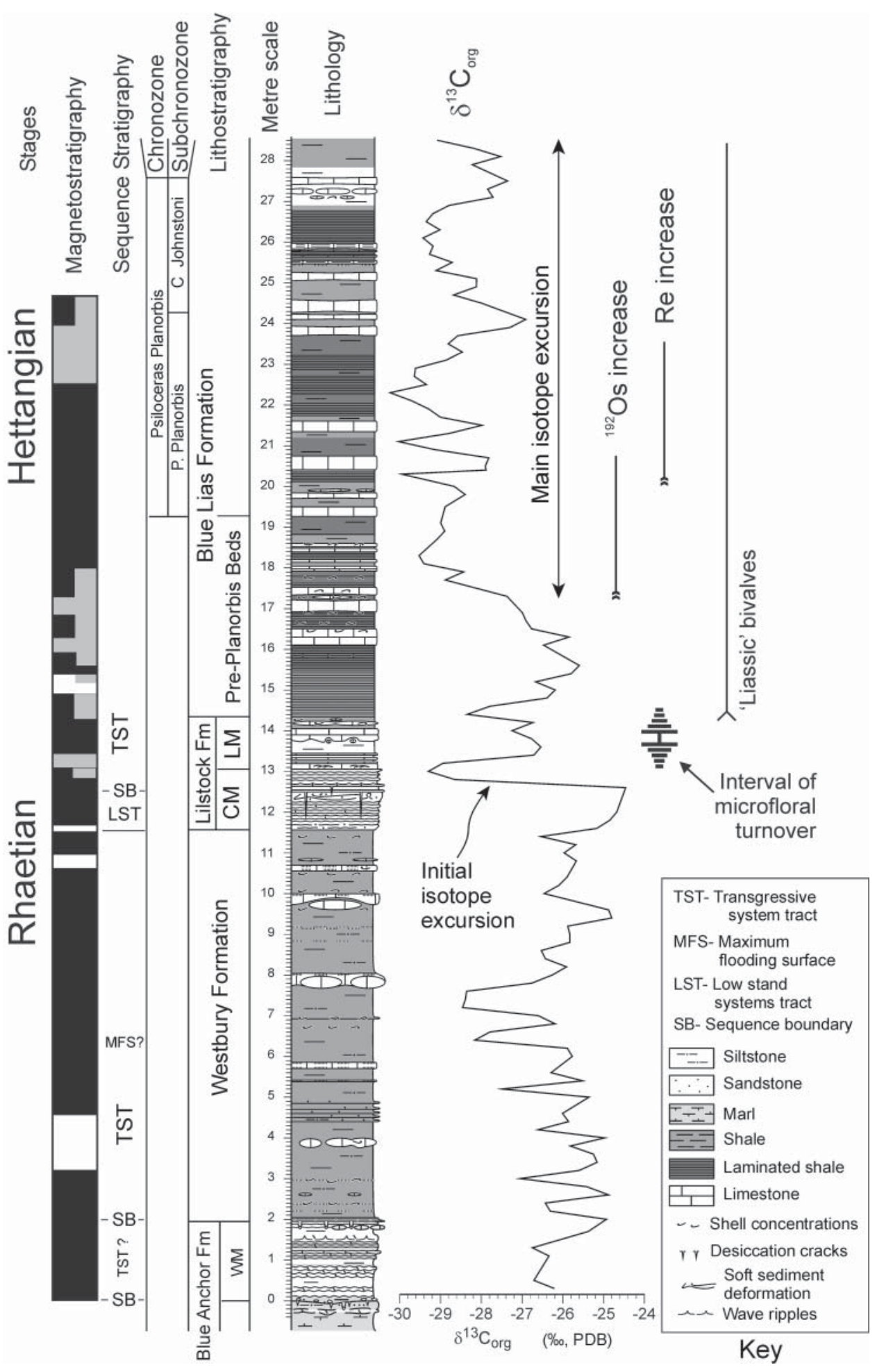

Fig. 13.20. The stratigraphy and indicators of environmental change (organic carbon isotopes $-\delta^{13} C_{\text {org }}$, flora changes, etc.) in the Penarth Group and basal Blue Lias Formation (St Audries Bay, North Somerset). CM, Cotham Member; LM, Langport Member; WM, Williton Member. Compiled from Cohen \& Coe (2002), Hesselbo et al. (2002, 2004) and Hounslow et al. (2004).

profiles, attesting to periods of emergence and soil development, prior to deposition of the shelly grey mudstones of the Langport Member (Fig. 13.19) (Wilson et al. 1990). In NE England the Cotham Member contains intervals of reddishbrown mudstone, which suggests a return here to playa-type depositional conditions similar to those of the Mercia Mudstone Group (Swift \& Martill 1999).

\section{The Triassic-Jurassic boundary succession and global environmental change}

The demise of ceratitine ammonoids, bivalves, conodonts, coral and crinoid groups from the Mid Triassic to the end-Triassic contributed greatly to the apparent extinctions of Triassic fauna before the Jurassic commenced. Raup \& Sepkowski (1984) 
estimated that $76 \%$ of all species became extinct from the Mid to the latest Triassic. Tanner et al. (2004) reviewed the nature of these extinctions by considering both the global statistics on genera and species abundance, in addition to fossil records from sections. This conjunctive approach led them to reiterate that the Late Triassic saw a demise in both terrestrial and marine organisms during, possibly in an out of phase, stepwise manner. In British strata this stepwise loss in species cannot be evaluated, since much of the Upper Triassic succession is devoid of fossils until the Rhaetian Penarth Group. Hence, the rapid changes in both flora and fauna seen in Britain are restricted to the last phase of a punctuated or gradual demise. The causes of this demise are uncertain.

Firm evidence has been found of bolide-impact ejecta spherules and shocked quartz, probably from the Manicougan impact site in northern Canada, in a Norian red-bed succession from the Branscombe Mudstone Formation in the Bristol region (Walkden et al. 2002). This event predates the base of the Jurassic by about $14 \mathrm{Ma}$, and hence could in part contribute to the stepped-extinction hypothesis. One of the major losses in diversity in the marine environment took place in the transition from the Norian into the Rhaetian (Tanner et al. 2004). The postulated global sea-level drop during the Rhaetian may be responsible for this loss through reduction of marine habitats, although this cannot explain the changes in the terrestrial realm (Tanner et al. 2004).

The causes of the extinctions across the Rhaetian-Jurassic boundary are uncertain, but processes which have been implicated are: (a) bolide impact and a consequent increase in atmospheric opacity; (b) major changes in $\mathrm{CO}_{2}$ content of the atmosphere (McElwain et al. 1999; Beerling \& Berner 2002); (c) expulsion and out-gassing of large quantities of flood basalts from the central Atlantic magmatic province (Marzoli et al. 2004); (d) sea-level change; and (e) release of methane from sea-floor methane hydrates (Wignall 2001a).

Speculative evidence of a bolide impact occurs in the form of deformed and slumped beds in the Cotham Member in England and Northern Ireland (Simms 2003). This appears to occur at approximately the same level as a modest Ir-anomaly in some eastern North America sections, thought to be associated with the impactor material (Olsen et al. 2002).
During the latest Rhaetian and earliest Jurassic, there were two major perturbations in the global carbon cycle, evident by two negative excursions in the organic carbon isotopic signal seen in British sections (Fig. 13.20). The first of these, of apparently shorter duration, occurs within the Cotham Member, above the shrinkage-cracked bed. The second, of perhaps longer duration, starts within the Pre-Planorbis Beds of the Lias Group and appears to be coincident with Os and Re abundance changes in the mudstones. Cohen \& Coe (2002) have interpreted the Os and Re abundance changes as indicating the initial weathering of the flood basalts from the Central Atlantic magmatic province (CAMP), suggesting that massive extrusion of basalts from CAMP and their out-gassing were responsible for the younger isotopic excursion. The origin of the older isotopic excursion is uncertain, but may also be linked with outgassing of flood basalts in North Africa (Marzoli et al. 2004).

The spore and pollen data record a major turnover of Triassic microflora within the middle-upper part of the Lilstock Formation (Edwards 1999; Hounslow et al. 2004), prior to the younger isotopic excursion in the Pre-Planorbis Beds. The major spore and pollen changes are slightly younger than the initial perturbation in the organic carbon isotope record in the Cotham Member (Hesselbo et al. 2002). Hence, in England and Wales there appears to be a sequence of significant 'environmental events' (Fig. 13.20). The earlier carbon isotopic event pre-dates fundamental changes in the spore and pollen flora (and perhaps the marine microfauna), and closely post-dates the lowstand in sea level in the Cotham Member. The later carbon isotopic event follows a transition interval into a typical 'Jurassic-type' bivalve fauna within the Pre-Planorbis Beds. Establishment of ammonoids that are considered to be typically Jurassic in character follows later when Psiloceras appears. The changes in atmospheric $\mathrm{CO}_{2}$ content inferred by McElwain et al. (1999), from changes in fossil-leaf stomata size, in strata spanning the Triassic-Jurassic boundary in Greenland, cannot easily be related to the sequence of events seen in the UK. The increase in inferred atmospheric $\mathrm{CO}_{2}$ in Greenland is probably across a minor hiatus but is also linked to a major turnover from Triassic to Jurassic-type flora (Hesselbo et al. 2002), implying there were also major climatic changes in the transition from the Rhaetian into the Jurassic. 